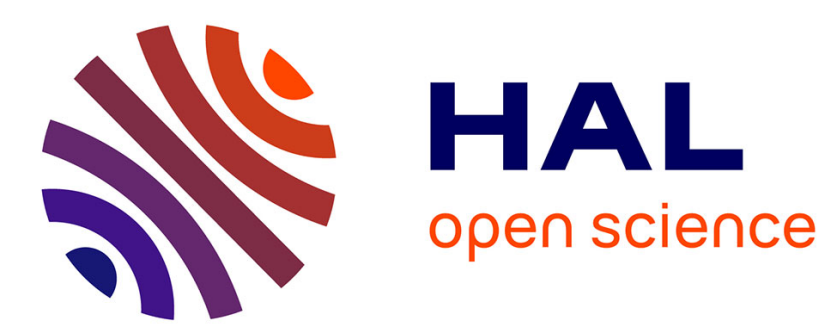

\title{
The effects of expanding the generosity of statutory sick leave insurance: the case of a French reform
}

\author{
Mohamed Ali Ben Halima, Malik Koubi
}

\section{To cite this version:}

Mohamed Ali Ben Halima, Malik Koubi. The effects of expanding the generosity of statutory sick leave insurance: the case of a French reform. 2021. halshs-03351470v2

\author{
HAL Id: halshs-03351470 \\ https://shs.hal.science/halshs-03351470v2
}

Preprint submitted on 23 Sep 2021

HAL is a multi-disciplinary open access archive for the deposit and dissemination of scientific research documents, whether they are published or not. The documents may come from teaching and research institutions in France or abroad, or from public or private research centers.
L'archive ouverte pluridisciplinaire HAL, est destinée au dépôt et à la diffusion de documents scientifiques de niveau recherche, publiés ou non, émanant des établissements d'enseignement et de recherche français ou étrangers, des laboratoires publics ou privés.

\section{(1) (1) $\$$}

Distributed under a Creative Commons Attribution - NonCommercial - NoDerivatives| 4.0 


\section{le cnam \\ ceet}

Septembre

2021
The effects of expanding the generosity of statutory sick leave insurance: the case of a French reform

Mohamed Ali Ben Halima Malik Koubi 
"Le Descartes »

29, promenade Michel Simon

93166 Noisy-le-Grand CEDEX/

Téléphone: (33) $014592 \quad 6800$

ceet.cnam.fr 


\title{
The effects of expanding the generosity of statutory sick leave insurance: the case of a French reform
}

\author{
Mohamed Ali Ben Halima \\ mohamed.benhalima@lecnam.net
}

Centre d'Etudes de l'Emploi et du Travail (CEET-CNAM), LIRSA, TEPP

MALIK KOUBI

malik.koubi@travail.gouv.fr

DARES, Centre d'Etudes de l'Emploi et du Travail (CEET - CNAM)

\section{DOCUMENT DE TRAVAIL}

\section{No 208}

septembre 2021 
Directrice de publication | Christine Erhel Secrétaire de rédaction | Bilel Osmane 


\title{
THE IMPACT OF EXPANDING THE GENEROSITY OF STATUTORY SICK LEAVE INSURANCE IN THE FRENCH PRIVATE SECTOR
}

\author{
MOHAMED ALI BEN HALIMA and MALIK KOUBI*
}

\begin{abstract}
This study evaluates the impact of the French reform of 11 January 2008 in the private sector, which modified the share of sick leave paid by the employer in addition to the social security benefit. The reform is comprised of two parts: the waiting period until complementary payment is made by the employer, reduced from ten to seven days; and the minimum required tenure to be eligible, reduced from three years to one year.

In this study, we used the administrative panel data (Hygie) from 2006 to 2010 along with a new collective bargaining agreement (CBA) database. The latter was constructed by the authors in order to collect the parameters of complementary benefit for sick leave. We examined separately the effects of the waiting period part and the tenure part of the reform, using a difference-in-differences strategy with matching.

When the waiting period is reduced, the number of sick days' increases significantly $(+0.5$ days). When the minimum tenure requirement is reduced, there is more impact on sick leave $(+0.6$ days on the number of sick days and $+0.9 \mathrm{pp}$ on sickness probability). The effects of sick pay reform are different between men and women. The waiting part of the reform significantly increased the annual number of sick leave days and the frequency of sick leave for men, while the Tenure part of the reform has significant impact only for women.
\end{abstract}

Key words: sickness absence; complementary benefit of sick leave; administrative panel data; difference-in-differences; health policy reform

\footnotetext{
* We would like to thank all those who participated in the seminars held by The Employment and Labour Research Centre (CEET) in 2019 and in the EALE, SOLE conferences. We would like to especially thank Joseph Lanfranchi, Christine Erhel and Mathieu Narcy for their feedbacks.

We acknowledge financial support from the Agence Nationale de la Recherche (ANR) under the grant number ANR-18CE26-0014 for the project "Absenteeism: firms' practices and public policies - APEPP"
} 


\section{L'impact de l'extension de l'indemnité complémentaire des arrêts maladie dans le secteur privé en France}

\section{Résumé}

La réforme issue de l'Accord national interprofessionnel (ANI) du 11 janvier 2008 vise à améliorer le niveau conventionnel de l'indemnité complémentaire des arrêts maladie versée par l'employeur. Scindée en deux volets, cette réforme réduit, d'une part, le délai de carence de l'indemnité complémentaire de 10 jours à 7 jours et, d'autre part, le critère de l'ancienneté minimale (de 3 ans à 1 an) pour bénéficier de l'indemnité complémentaire.

Dans cette étude, nous utilisons un panel des données administratives Hygie de 2006 à 2010 enrichi par une nouvelle base de conventions collectives, construite par les auteurs, qui recueille les paramètres d'indemnisation complémentaire des arrêts maladie. Nous évaluons séparément les deux volets de la réforme, délais de carence et réduction de l'ancienneté minimale sur les arrêts maladie en utilisant la méthode de différence de différences avec appariement.

Pour le volet carence, la réforme a un impact positif et significatif sur les absences, mesurées en termes de nombre annuel de jours d'absence (+0,5 jours). Pour le deuxième volet ancienneté, la réforme a impact significatif (+ 0,6 jours d'absence maladie $+0,9$ pp la probabilité annuelle d'absence pour cause de maladie). La réforme a un impact différent entre les hommes et les femmes. Le volet carence de la réforme a augmenté de manière significative le nombre annuel de jours d'absence et la probabilité d'arrêt maladie pour les hommes, tandis que le volet ancienneté de la réforme n'a un impact significatif que pour les femmes.

Mots-clefs : arrêt maladie, indemnité complémentaire des arrêts maladie, panel de données administratives, différence de différences, réforme d'arrêt maladie 


\section{INTRODUCTION}

Sickness insurance aims at protecting employees against income losses due to workplace absence for health reasons, by replacing wages at least partially during their absence. As with any public health policy, the effectiveness of sickness insurance benefits is measured by the ability to reconcile the objective of universal coverage for sickness absence and the cost of work absence.

In France, around one fifth of workers are absent from work each year. The total sick leave payments by the social security fund amounted to 11 billion euros in 2007, which rose steeply thereafter: 12.6 billion euros in 2010 and 14.4 billion euros in 2017. These expenditures constitute a key issue for French public finances, and give rise to several other concerns like labour costs, productivity and health outcomes. Health policy must address the recent rise in the cost of workplace absence and also protect the health and well-being of workers.

In the French private sector sickness benefit system, the Social Security scheme provides a common and universal base with a $50 \%$ replacement rate after a three days waiting period. In addition, the employer provides a so-called "complementary benefit". The law sets minimum requirements for the complementary benefit but employers are free to go beyond these requirements. In all, the complementary benefit represents a significant part of employee compensation. It is fixed by the professional branch to which the company belongs through a collective bargaining agreement (CBA).

This study evaluates the impact of the reform "Accord National Interprofessionnel" (ANI) of 11 January 2008, that extended complementary benefit in the French private sector and reduced the eligibility requirements. It took effect on 1 July 2008. The 2008 ANI reform modified two important parameters of complementary benefit. Firstly, the minimal tenure for an employee to be eligible to complementary benefit was reduced from three years to one year. We will call this the "tenure part" of the reform or simply T-part. The employees affected by the T-part of the reform became eligible for a higher sickness benefit combining the social security benefit and the complementary benefit. Secondly, the waiting period for an employee eligible to receive complementary benefit after the beginning of the period of absence was reduced from ten days to seven days. This is what we call the "waiting period part" of the reform or WP-part. Our identification strategy relies on well-defined control groups and the use of difference-in-differences (DID) approaches. The contribution of this study is twofold. On the one hand, we document the disparities in compensation that exist between the employees in relation with their CBA's settings, and for this purpose we analysed the legal content of the 46 main collective agreements. The complementary benefit was until now poorly documented and proves to be heterogeneous from one CBA to another. On the other hand, we estimate the causal impact of the T-part and the WP-part of the reform on work absences due to illness in France and confirm a positive impact of both folds of the 
reform. We exploit the heterogeneity of CBAs to define adequate control groups in a difference-indifferences approach.

\section{Determinants of sickness absence}

According to the economic literature, sickness insurance and sick leave benefits are the one of the factors explaining sickness absence (Allen, 1981; Barmby et al., 1995; Frick and Malo, 2008; Ziebarth and Karlsson, 2014; Ben Halima, Regeart and Koubi, 2018). The empirical studies find a positive correlation between the level of sick leave benefits and the number of annual sick days.

The determinants of sickness absence are potentially numerous and vary greatly over the publications: health status, gender, income level, working conditions and sickness insurance. Economic research on absenteeism can be grouped into three categories (Afsa and Givord, 2009).

The classic work-leisure trade-off is the simplest model (Allen, 1981), with the drawback that incentives are supposedly essentially monetary. Employees seek to maximize their utility function under budgetary constraints. Periods of absenteeism are adjusted according to the loss of earnings and applicable monetary penalties. This result is confirmed by an empirical study conducted on French medicoadministrative data showing that an employee's current wage has a negative effect on the duration of sick leave and that high wage increases over the long term tend to reduce sick leave duration among men and increase duration among women (Ben Halima and Regaert, 2012, 2013).

Certain studies have emphasized on the level of work effort supplied by the employee with work attendance as a modality. In the absence of information on an employee's health status, the work effort supplied can be interpreted in terms of moral hazard. In this context, a reduction in sickness insurance coverage levels (wage-replacement rate) reduces the rate of absenteeism.

The second group follows Shapiro and Stiglitz's (1984) model, which distinguishes the utility of work attendance from the utility of non-attendance. Employees choose the level of effort guaranteeing an income level that maximizes their utility. Absenteeism can thus represent the difference between the effort expended and the contracted working hours. As employers are unable to fully understand Employee's reasons for missing work due to sickness (due to a lack of awareness of the worker's effort and health status), they are consequently confronted with the classic problem of moral hazard.

Taking health status into account as a factor determining the utility of attending work constitutes the third approach, which attempts to reintroduce the notion of health status as a decisive variable in taking sick leave. Without being totally absent in the first two groups (Allen, 1981; Barmby et al., 1995; Galizzi and Boden., 2003), the health status dimension is not a core element of their paradigms. Health-related absenteeism is no longer an individual choice (work-leisure trade-off; effort function) but can be the result of deteriorated health status, either through illness or difficult working conditions (Ose, 2005).

Recent studies (Afsa and Givord, 2009) have effectively underlined the significant role played by working conditions in Employee absenteeism. Grignon and Renaud (2007) dissociated sick leave, the 
result of Employees' choices (ex post moral hazard), from absenteeism due to working conditions, which is the responsibility of the employer, by controlling for health status (ex-ante moral hazard). German studies have assessed the impact of a German reform on employees' behaviour in terms of sick leave. The reform increased the mandatory sick leave benefits from $80 \%$ of the wage to $100 \%$. The main result is that expanding the generosity of the sickness insurance system increases the frequency and duration of sickness absence (Ziebarth and Karlsson, 2014).

De Paola et al. (2014) analyse the absence behaviour after an Italian public reform in 2008. The new reform aims to reduce sick leave compensation and increase monitoring. The authors find that the employees' probability of being absent diminishes.

Then, the implementation of a policy to cut sick pay in Estonia in 2009 reduced the wage replacement rate from $80 \%$ to $70 \%$ and delayed payment until the $9^{\text {th }}$ day of sick leave, instated of the $2^{\text {nd }}$ day before reform. The reform resulted in a reduction in the total number of sick-leave episodes and persons listed as sick decreased by one third (Aaviksoo and Kiivet, 2016).

Swedish study found a significant impact from a change in the level of sick leave compensation on sick leave behaviour. Reforms increasing the level of sick leave benefits induce a continuous increase of sickness absence (Henrekson M. and Persson, 2004). Another empirical evaluation looks at a Swedish policy reform which consisted in the abolishment of a waiting period of one day and an increase in the benefit levels for sick leave durations shorter than 14 days. This reform reduced by three-percent the total number of sick days (Pettersson-Lidbom et al., 2013).

The rest of the paper is organized as follows: section 2 describes the French sick pay system and sick leave reform. Section 3 presents the data sources. Section 4 details the econometric methodology. Section 5 presents the results for the waiting period and the tenure parts of the reform. Finally, we resent the discussion of the results and the conclusion.

\section{The French sickness benefit system and the changes brought by the 2008 reform}

The French sickness benefit is jointly financed by the Social security and the employers. The Social Security scheme provides a common and universal base with a $50 \%$ replacement rate after a three-day waiting period (Cf. Appendix 1). That is to say, the compensated employee receives $50 \%$ of his daily wage from the 4th day [Fig. 1].

In addition, the employer provides a so-called "complementary benefit". The law sets the minimum requirements for the complementary benefit and the actual compensation level is set by the CBA in accordance with the law (Ben Halima and Koubi, 2018). Of course CBA settings can be (and often are) more generous than the minimum requirement. Until now, complementary benefits were not officially quantified for lack of information but they represent significant amounts of money. This unique organisation has its origins in the history of French social protection, which was initially built on the 
basis of professions and guilds. This organisation is still a source of inequality between employees. Indeed, depending on the CBA negotiated at industry level, firms may cover all or part of the three-day Social Security waiting period, reduce the employer's ten-day waiting period, increase the wage replacement rate or extend the benefit period. The CBA is key to determining the precise parameters of compensation that apply to each employee but has not been documented until now. A large part of the work and originality of this study lies in the compilation of a CBA database that gathers the indemnification parameters of the CBAs from the texts of the CBAs in order to infer the real levels of compensation of each employee in our data.

The law sets in particular two parameters that were modified by the 2008 reform under review:

- The minimum required tenure for an employee to be eligible to the complementary benefit. This parameter was set to 3 years before the reform and was reduced to 1 year. Note that some CBAs were not impacted by the reform because eligibility in these CBAs was already set to 1 year.

- The maximum waiting period from the beginning of the absence spell before a sick employee can receive the complementary benefit. This parameter was set to 10 days before the reform and was reduced to 7 days. Here again, some CBAs were not affected because they were, already before the reform, more generous than the minimum requirement set after the reform.

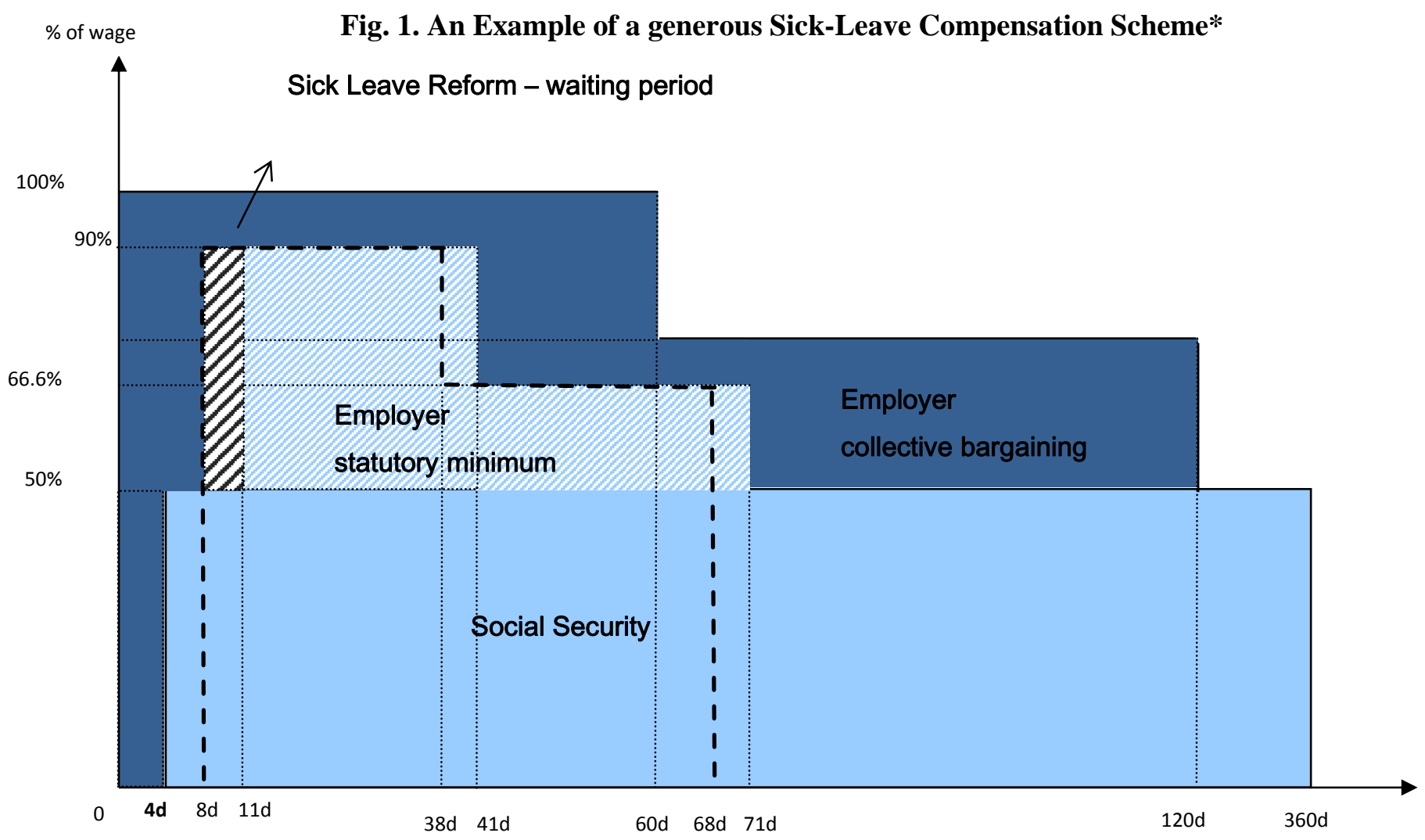

Social security

Employer statutory minimum

Employer collective bargaining* (example)

* Reading: Compensation chart for an executive with one-year tenure on the first day of non-work-related sickness absence under collective agreement IDCC 493 (National Collective Agreement for wines, fruit juices, syrups, spirits and liquors of France). 
Apart from the waiting period, the day-profile of the wage replacement rate was not modified by the reform. The minimum requirement set by the law for this profile is the following: after the waiting period, a period of at least 30 days with a total replacement rate of $90 \%$ (Social security + complementary benefit) and another 30 days with a wage replacement of $66 \%$.

Typically, an employee with 1 year of seniority in a basic CBA received before the reform only the social security part (50\% replacement wage from the $4^{\text {th }}$ day of the absence spell). After the reform, he was eligible for the complementary benefit and his replacement rate is still $50 \%$ from days 4 to 7 , but then rises to at least $90 \%$ at the $8^{\text {th }}$ day and afterwards. Similarly, for a typical employee with a 10 daywaiting period before the reform, the replacement rate rises after the reform from $50 \%$ to at least $90 \%$ on days 8,9 and 10 because of the reduction of the waiting period. The change brought by the reform is quite huge in the first case and also quite important in the second case.

\section{DATA}

\section{The Hygie Database provides detailed information on sick leave spells}

The database used in this study combines two data sources: the administrative Hygie database (20062010) and the CBA database compiled by the authors for the purpose of this study.

The Hygie database provides a detailed description of sick leave spells for a representative sample of General Health Insurance scheme beneficiaries. It constitutes a unique source of information that has its origins in the study of the mechanisms of sick leave in the private sector conducted by the Institute for Research and Information in Health Economics (IRDES) following a call for tender launched by the Ministry of Health Directorate for Research, Studies, assessment and Statistics (DREES). The database was created in order to carry out the required research and contains necessary information both on Employees' sick leave behaviour and associated healthcare consumption, Employees' individual and professional contexts and a number of characteristics concerning the companies employing them.

The 2006-2010 HYGIE data are issued from the merger of Pension Fund (CNAV) data and Health Insurance Fund for Salaried Workers (CNAMTS) data. More specifically, files were extracted from the National Career Management System (SNGC) grouping together all private sector Employees in France, and the National Statistical Beneficiary System (SNSP) grouping together all private sector retired people, matched with sickness benefits data taken from the National Health Insurance Inter-regime Information System (SNIIR-AM). CNAV data constituted the point of entry with a random sample of beneficiaries aged from 22 to 70 years old having contributed to the general pension fund at least once 
during their lives. The CNAMTS data concerns both primary and secondary beneficiaries of the General Health Insurance scheme who received sickness benefits for at least one spell of sick leave during the year 2004 and/or 2005. Matching CNAV and CNAM-TS data sources enabled the construction of the Hygie database panel composed of 538,870 beneficiaries from 2005 to 2010.

The 2006-2010 Hygie database contains a random sample of employees working in the private sector and aged 22 to 70 years. It combines two sources. More specifically, files were extracted from the National Career Management System (SNGC) grouping together all private sector Employees in France, and the National Statistical Beneficiary System (SNSP) grouping together all private sector retired people, matched with sickness benefits data taken from the National Health Insurance Inter-regime Information System (SNIIR-AM).

CNAV data constituted the point of entry with a random sample of beneficiaries aged from 22 to 70 years old having contributed to the general pension fund at least once during their lives. The CNAMTS data concerns both primary and secondary beneficiaries of the General Health Insurance scheme who received sickness benefits for at least one spell of sick leave during the year 2004 and/or 2005. Matching CNAV and CNAM-TS data sources enabled the construction of the HYGIE database panel composed of 538,870 beneficiaries from 2005 to 2010 .

The French general pension fund (CNAV) which contains a wide range of variables on workers' status in the labour market and employer's characteristics. The second source comes from the National Health Insurance (CNAMTS) and provide a detailed information of health like medical consumption and sick leave: start date, end date and the number of sick leave absence during the year.

The panel constitutes a representative sample of private sector Employees and includes precise information on Employees, the companies employing them and their healthcare consumption. This weighting was used to estimate global cost (not the econometric estimates).

\section{An Innovative database on Collective Bargaining Agreements (CBAs)}

The study strongly relies on an original CBA database that gathers the indemnification parameters of the main CBAs. The authors compiled this database by analysing the portions of the CBA documents concerning sickness benefit provision, and by extracting information about the complementary benefit scheme within each CBA in the form of parameters such as the length of the waiting period, the dayby-day replacement rate according to employee's tenure, etc.

Indeed, although full texts of the CBA are available on the LégiFrance government website, this information has not been formatted for statistical use. Moreover, the various CBAs are not presented in a uniform manner, they do not include the same level of detail, and the basic texts have often been amended by subsequent agreement. 
It was therefore necessary to undertake a non-trivial effort in compiling, ordering the texts from the initial agreement to the most recent changes, identifying the parts of the texts referring to the sick pay scheme and finally coding the compensation schemes into a statistical database. CBAs were very concentrated in France in 2007. There were more than 700 CBAs but the few most important covered the majority of employees. We were able to encode the 46 most representative French CBAs and to construct a statistical database precisely describing the sick pay scheme of each of those CBAs with a few parameters ${ }^{1}$. We have identified 79 different sickness benefit provisions, taking into account the provisions according the occupational category of workers and the new amendments during the study period.

Out of this work we built an innovative data set describing the indemnification scheme of the 46 most representative CBAs, covering $60 \%$ of the Employees of the Hygie database. In the majority of cases, CBAs make provisions for different sickness benefit plans according to employee categories.

The database provides a complete description of each indemnification scheme. The main variables used here are related to employer waiting period (WP) and minimum tenure requirement, but the database also describes other indemnification parameters (like benefit durations and wage-replacement rates).

The structure of the WP is very different depending on the socio economic class (cf. Table 1). Most executives have a WP equal to zero (69\%). On the other hand, only $17 \%$ of the employees and $27 \%$ of the laborers have a WP equal to zero. We can see that there are more employees and laborers with a high WP than Supervisors and executives.

Table 1: Waiting Period Distribution in 2007, By Category

\begin{tabular}{ccccccccc}
\hline Waiting period (WP) & \multicolumn{2}{c}{ Executives } & \multicolumn{2}{c}{ Supervisors } & \multicolumn{2}{c}{ Employees } & \multicolumn{2}{c}{ Laborers } \\
\hline 0 & 12,504 & $69 \%$ & 5,912 & $46 \%$ & 5,440 & $17 \%$ & 5,918 & $27 \%$ \\
3 & 1,901 & $10 \%$ & 3,499 & $27 \%$ & 8,331 & $26 \%$ & 5,681 & $26 \%$ \\
5 & 0 & $0 \%$ & 0 & $0 \%$ & 774 & $2 \%$ & 2,232 & $10 \%$ \\
6 & 233 & $1 \%$ & 140 & $1 \%$ & 490 & $2 \%$ & 525 & $2 \%$ \\
7 & 195 & $1 \%$ & 451 & $3 \%$ & 909 & $3 \%$ & 190 & $1 \%$ \\
8 & 0 & $0 \%$ & 692 & $5 \%$ & 4,638 & $15 \%$ & 879 & $4 \%$ \\
10 & 3,339 & $18 \%$ & 2,244 & $17 \%$ & 11,399 & $36 \%$ & 6,466 & $30 \%$ \\
\hline Total & 18,172 & $100 \%$ & 12,938 & $100 \%$ & 31,981 & $100 \%$ & 21,891 & $100 \%$ \\
\hline
\end{tabular}

Note: this table shows the distribution of the waiting period WP in 2007, by category. $69 \%$ of executives had no waiting period in case of sickness absence.

Source: CBA database compiled by authors.

\footnotetext{
${ }^{1}$ CBA are very concentrated: according to the Ministry of Labour, of the thousand or so existing CBAs, just under 250 cover more than 5000 employees. Within a collective agreement there may be several different compensation schemes according to employees' position and tenure. We were able to encode the 46 most representative French CBAs and to construct a statistical database precisely describing the sick pay scheme of each of those CBAs with a few parameters.
} 
The first measure of the reform we consider is a reduction of the waiting period from 10 days to 7 days. Before the reform, complementary benefit provision used to start at the latest on the 11th day of the sickness spell. After the reform, the complementary benefit provision begins at the latest on the 8th day. In other word, the level of indemnification improved for all employees with a waiting period longer than 7 days in 2007 and fulfilling the minimal tenure condition (which is the case for all employees with 3 years tenure or more). For example, the wage-replacement rate for employees with a 10-day waiting period rose from $50 \%$ to at least $90 \%$ on days 8,9 and 10 of any sickness spell (Figure 2). On the contrary, indemnification conditions remained unchanged for employees with a waiting period less or equal to 7 days in 2007.

Fig. 2. Distribution of employees, according to their waiting period length, in 2007 and 2009 2007 2009
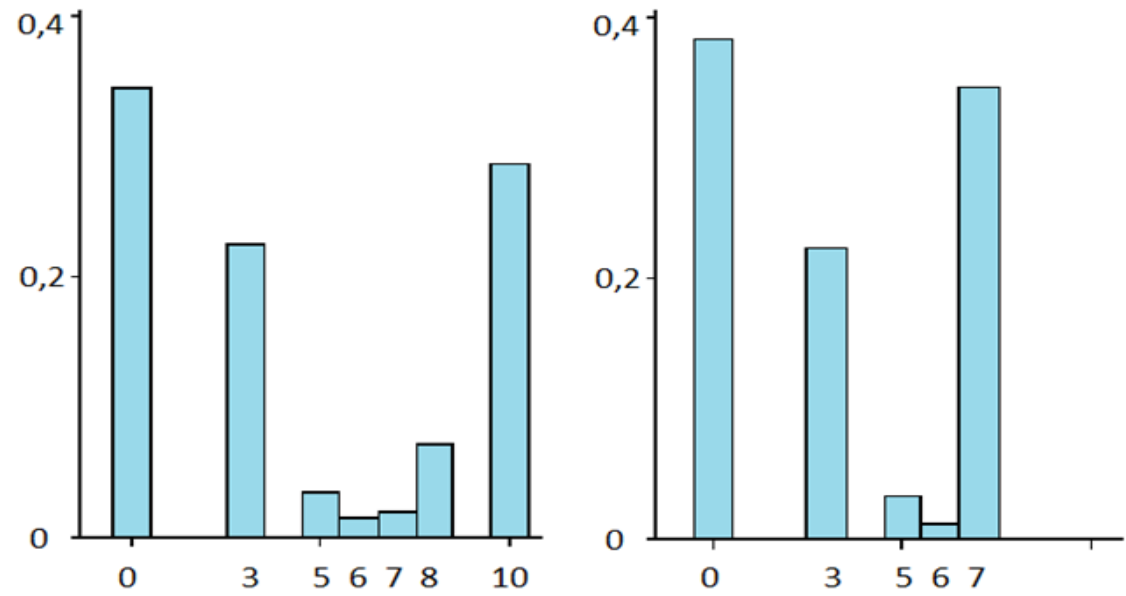

Note: these two graphics represent the distribution of employees in 2007 and 2009, according to the waiting period length of their CBA (WP). In 2007, more than $30 \%$ of employees had a WP between 8 and 10 in our sample.

Source: CBA database compiled by authors.

The level of indemnification improved for all employees with a waiting period longer than 7 days in 2007 and fulfilling the minimal tenure condition (which is the case for all employees with 3 years tenure or more). For example, the wage-replacement rate for employees with a 10-day waiting period rose from $50 \%$ to at least $90 \%$ on days 8, 9 and 10 of any sickness spell (Figure 2). On the contrary, the indemnification conditions remained unchanged for employees with a waiting period less or equal to 7 days in 2007. Employees really affected by the reform are actually quite numerous. In 2007, $28 \%$ of employees in ours sample had a waiting period longer than 7 days, most of whom had indeed a 10-day waiting period (Figure 2).

Unlike the waiting period fold, employees really affected by the tenure fold of the reform are not very numerous because the treatment condition implies two restrictive criteria: the first criterion is to have less than 3 years of tenure and the second criterion is to have a minimum tenure condition superior to 1 
year in in 2007. Minimum tenure condition distribution shows that he second criterion is quite restrictive.

Table 2: Distribution of employees, according to their minimum tenure condition, in 2007

\begin{tabular}{ccc}
\hline Minimum tenure condition in 2007 & Frequency & Percent \\
\hline 0 & 4,245 & 3.07 \\
1 month & 4,520 & 3.27 \\
3 months & 1,503 & 1.09 \\
4 months & 919 & 0.66 \\
6 months & 6,062 & 4.38 \\
1 year & 75,028 & 54.22 \\
2 year & 3,657 & 2.64 \\
3 year & 42,440 & 30.67 \\
\hline Total & 138,374 & 100.00 \\
\hline Source: CBA database compiled by authors. &
\end{tabular}

Table 2 shows that $54 \%$ of employees are subject to minimum tenure condition of 1 year to be entitled to complementary benefit and $31 \%$ of 3 years. Even if the tenure fold of the reform is targeted on a small population, the reduction of minimal tenure drastically changed the indemnification level for treated individuals. Before the reform, they benefitted only from the Social security tier, namely a wagereplacement rate of $50 \%$ from the 4 th day of the sickness spell on. After the reform, their wagereplacement rate climbs up to $90 \%$ at least (Second tier: employer statutory minimum) and the provision period starts at the latest on the 8th day of the spell, which makes quite a difference.

\section{Merging the Hygie and the CBA databases}

To enrich the Hygie data base with CBA's indemnification parameters, we first merged the Hygie data base with an employer repertoire which gives for each employer the identifier of the CBA to which it is affiliated. In the French system of bargaining, every CBA is registered and receives an administrative identifier. We also know from the repertoire if the employer is not affiliated to any CBA, which is the case for about $15 \%$ of the sample.

The employer identifier $\left(\right.$ SIRET $^{2}$ ) and the CBA identifier (IDCC) ${ }^{3}$ allowed us to merge the HYGIE data base with our CBA data base and calculate indemnification parameters for all employees within the

\footnotetext{
2 The SIRET number is an identification number for French companies.

${ }^{3}$ The IDCC is an identification of collective agreements.
} 
analysed $46 \mathrm{CBA}$ as well as those not covered by any CBA. We restrict our analysis to individuals for which indemnification parameters are known (60\% of the initial sample).

\section{EMPIRICAL METHODOLOGY}

\section{Econometric model}

We examine the WP-part and the T-part of the reform independently. Our identification strategy relies on well-defined control groups and the use of difference-in-differences (DID) approaches with Kernel matching. We exploit differences in the indemnification settings at the CBA level for the complementary benefit in order to find adequate control groups. For the WP-part of the reform, we defined a list of collective bargaining agreements that were not impacted by the reform because the waiting period under those CBAs was already seven days or less before the reform. The control group can be selected among employees under those CBAs. For the T-part of the reform, nothing had changed for employees with three years tenure or more and the control group were selected among them.

Formally, we estimate the following equation:

$$
Y_{i}=\beta_{0}+\beta_{1} \delta_{\text {treated }}+\beta_{2} \delta_{\text {post-reform }}+\beta_{3} \delta_{D I D}+\beta_{i} X_{i}+\varepsilon_{i}
$$

Where $Y_{i}$ is the output for each employee: the annual number of absences and the annual probability of absence for sickness reasons. The deltas are dummies: $\delta_{\text {treated }}$ equals 1 if the individual is treated by WP-part or T-Part of the reform and 0 otherwise, $\delta_{\text {post-reform }}$ equals one if the observation is after the reform (2009-2010) and 0 if the observation is before reform (2006-2007), and $\delta_{D I D}=\delta_{\text {treated }} *$ $\delta_{\text {post-reform }}$ is the interaction of these two dummies while the coefficient associated $\beta_{3}$ is the parameter of interest. $X_{i}$ is a vector of covariates used in the estimates and in the matching which contains gender, age, department of residence, region, socio-professional category, salary, previous health indicators approximated by the number of visits to a general and specialist practitioners and the number of days of hospitalization, company size and sector, and the regional unemployment rate.

For the WP-part of the reform, we keep only employees with three years' tenure or more so that they were not affected by the tenure part of the reform. Within this group, the treated are those employees with a waiting period of eight to ten days. The Control group 1 is a subgroup with a waiting period between three and seven days. This constraint allows for the retention in the control group of employees whose average waiting period is closer to that of the treatment group.

For the T-part of the reform, we keep only employees in firms that required a three-year tenure for the employee to be entitled to complementary benefits before the reform. The treated employees are those with one or two years of tenure. The Control group 2 consists of all other employees with three-year 
tenure or more. Including all salaries for this second part of the reform is more relevant because from three years, the tenure does not impact the additional level of sick leave benefits covered by employers.

For the T-part, we therefore adopt a pseudo-panel strategy with a difference in difference. As tenure increases with time and groups are defined based on employee tenure, the composition of groups varies over time. Groups do not contain the same individuals before and after the reform. First of all, we have to discard employees affiliated to CBA with minimal tenure condition less or equal to one year in 2007 because within those CBA, no employee was treated. As almost minimal tenure conditions are one year or three years, we only keep the CBA with the years as minimal tenure in 2007. Treated 2 and control groups are defined according their tenure duration. Treated 2 are individuals with one and two years of tenure in 2007 and in 2009. The other fact to notice is that tenure mechanically increases for employees who don't change employer. Most individuals who don't meet the seniority condition in 2007 will actually do in 2009. And this independently of the reform. Just because they don't change employer between 2007 and 2009. It is important to separate this mechanical increase in tenure effect from the actual effect of the reform. This implies, in the difference-in-differences approach, to calculate evolutions of the outputs for individuals with the same tenure in the two periods rather than to compare outputs of the same people in the two periods. Within a given group, individuals are not necessarily the same in 2007 and 2009. In fact, most individuals are different in the treated group in 2007 and 2009. Indeed, as treated individuals must have one or two years tenure, they can hardly be the same in 2007 and 2009. Indeed, all individuals who don't change employer between 2007 and 2009 will have at least three years tenure in 2009 and will automatically meet the tenure condition independently of the reform. Table 3 shows the number of observations for the Treated and the Control groups for the two parts of the reform in our 2006-2010 sample. For the WP-part group, the treated group represents $32 \%$ for the men $(n=50,325)$ and $42 \%$ for the women $(n=63,956)$. For the T-part group, women are always more highly represented in the treated group, $41 \%$ for women and $33 \%$ for men. For the waiting period and the tenure parts of reforms, the Control groups $\mathrm{A}$ and $\mathrm{C}$ are more restricted compared to other Control groups and represent respectively in each group of reform, $29 \%(\mathrm{n}=89559)$ and $41 \%(\mathrm{n}=51566)$.

Table 3: Number of observations Treated and Control Groups - Two parts of reform

\begin{tabular}{lccc}
\hline & Men & Women & All \\
\hline Waiting period part of the reform & 155145 & 150532 & 305652 \\
Treated 1 (Waiting Period $>7$ ) & 50325 & 63956 & 114281 \\
Control 1 $(3 \leq$ Waiting Period $\leq 7)$ & 40861 & 48635 & 89559 \\
Tenure part of the reform & 59789 & 63581 & 123370 \\
Treated 2 (Tenure $1-2$ years) & 19985 & 26169 & 46154 \\
Control 2 (Tenure $\geq 3$ years) & 39804 & 37412 & 77216 \\
\hline
\end{tabular}

Note: This table shows the number of observations for the Treated and the Control groups for the two parts of the reform in our $2007-2010$ sample.

Source: Panel Hygie 2006-2010 and CBA database compiled by authors. 


\section{The Parallel trend assumption}

The estimation of the treatment effect in the DID analysis requires some assumption relating to trends for controls and treated in absence of treatment, the most common being the assumption of parallel trends of the outcome. This assumption implies that in the absence of treatment, the trends of the performance variable are similar for the control and treated groups and are assumed to be time-invariant. Fig. 3_provides graphical evidence on the validity of the parallel trend assumption for the both parts of reforms. Slightly different trends between the control and treatment groups are found. For the waiting period part of the reform, the probability of sickness increases from 2006 to 2007 more in the control group than in the treatment group.

The test on the dynamic common trend is the Wald test of the joint significance of all pre-treatment effects. The p-value for the Wald test is greater than 0.05 for all performance variables, number of sick days and the probability of sickness, and for both parts of reform. The conclusion of the test is that the controls and the treated have common pre-treatment dynamics for the both parts of reforms. We conducted this test for men and women and for both parts of reform, before matching, and the results of the test confirmed the same conclusion of the parallel trend assumption, obtained for all individuals (Fig. A1 and Fig. A2 in appendix).

We tested the parallel trend assumption for the matched sample. The results for the whole sample (Fig. A3), for men (Fig. A4) and for women (Fig. A5) confirm the common trend between the treated and control groups in pre-refom period (2006-2007). All Wald tests have p-value greater than 0.05 , which confirm the common pre-treatment dynamics hypothesis is valid. 
Fig. 3. Time trends absence for the both part of reforms in 2006-2010

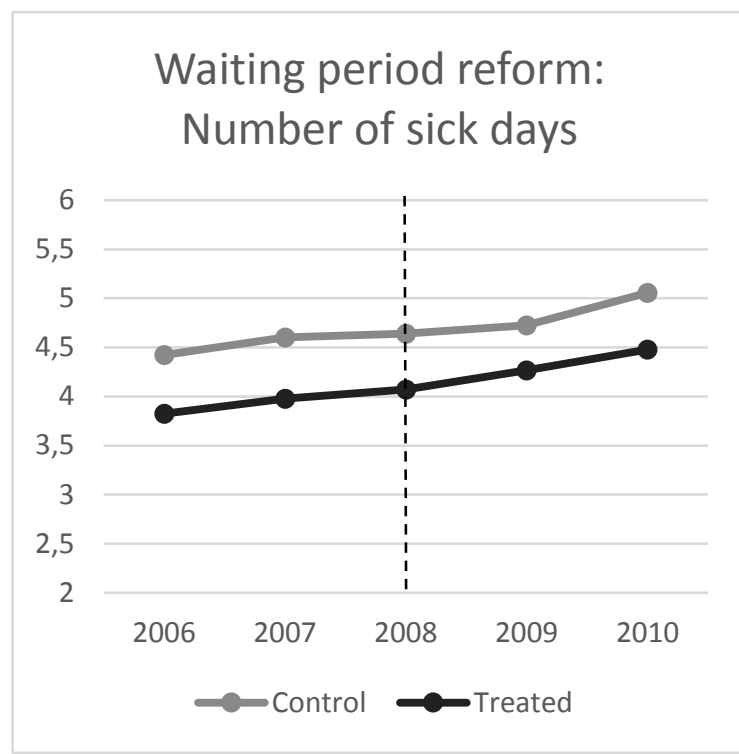

Common Trends Test*: 0.006

P-value : 0.934
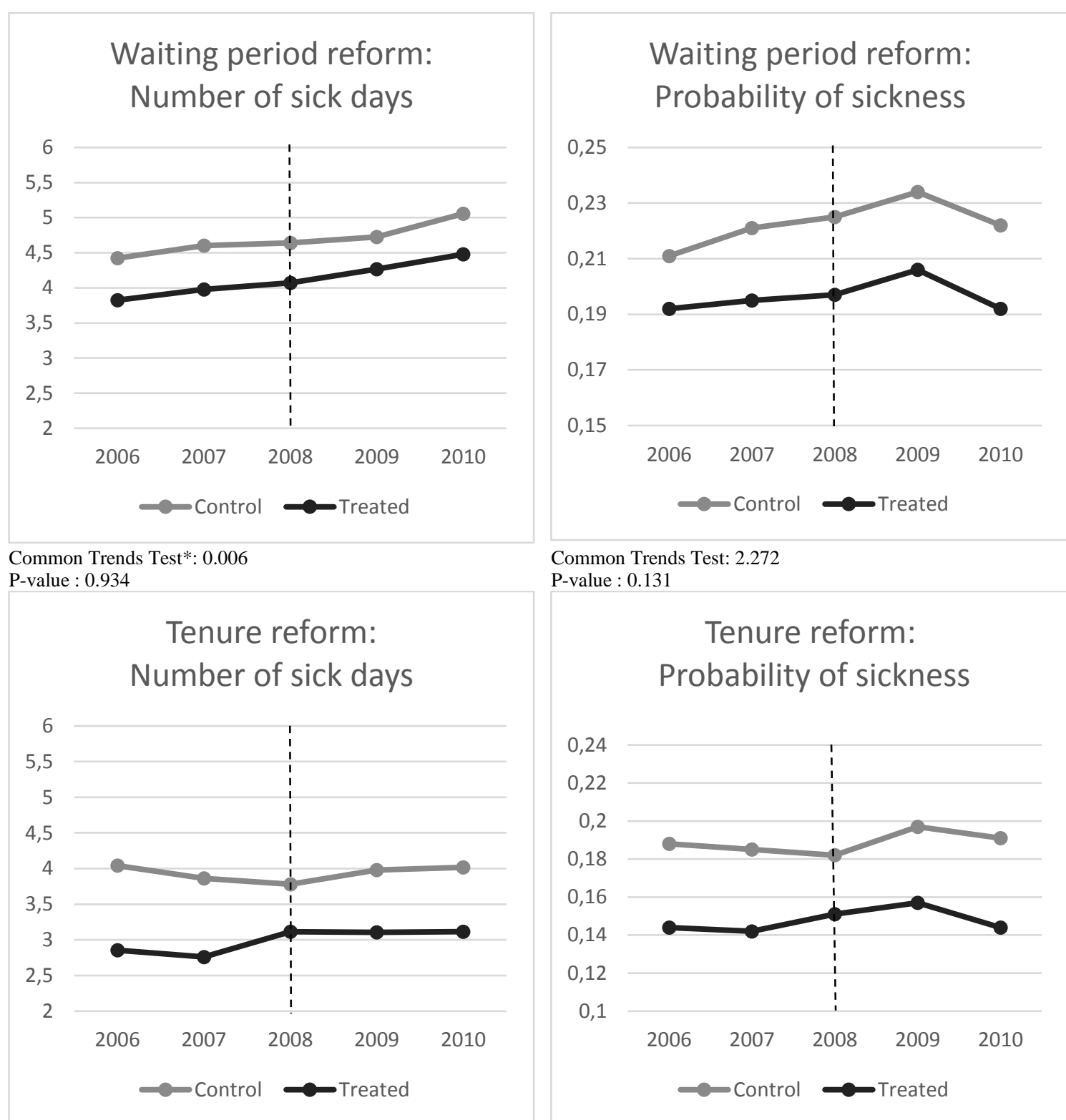

Common Trends Test: 2.272

P-value : 0.131

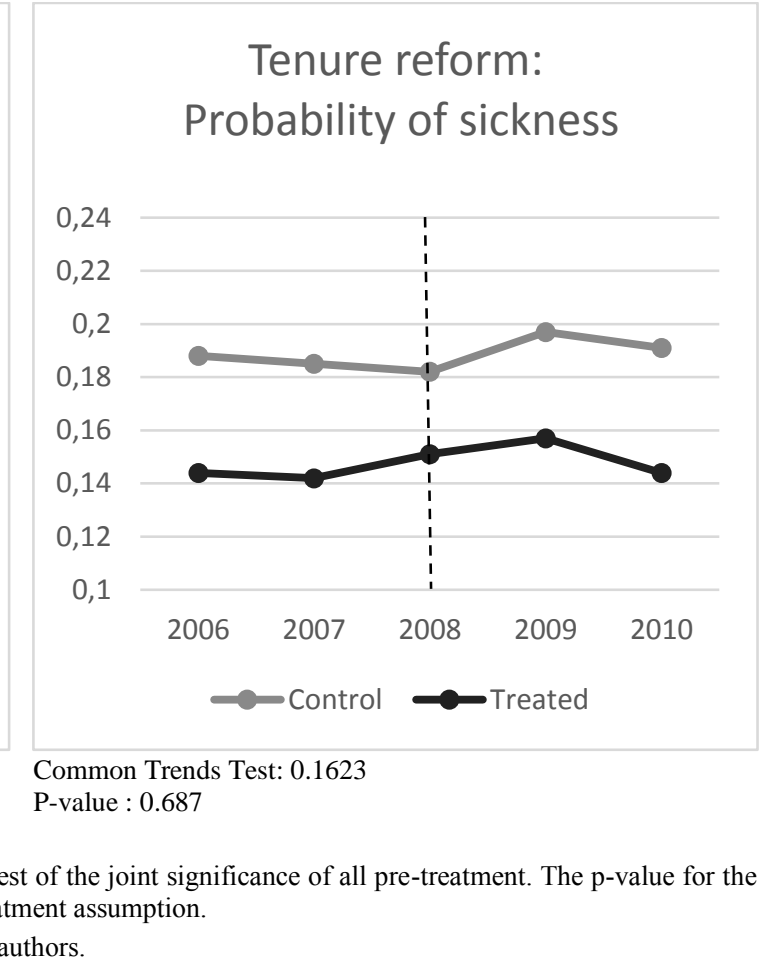

Wald test is greater than 0.05 confirm the common trend pre-treatment assumption.

Source: Panel Hygie 2006-2010 and CBA database compiled by authors.

\section{Balancing test and descriptive statistics before and after matching}

The aim of the matching technique is to reduce baseline bias using the propensity score with Kernel matching. Table 4 shows five indicators obtained before and after matching by presenting such as the Pseudo-R2, Mean Bias, Median Bias and the two indicators of Rubin. The B-Rubin is the absolute standardized difference of the means of the linear index of the propensity score, and the R-Rubin is the ratio of treated to non-treated variances of the propensity score (Rubin, 2001).

Firstly, Table 4 presents the results of the Pseudo-R2 obtained from probit estimation of the conditional treatment probability (propensity score) on all the variables. The results show that the Pseudo-R2 is 
lower after matching. The Pseudo-R2 decreases, for all sample, from 0.258 to 0.08 (WP-part) and from 0.194 to 0.003 (T-part). We can conclude that after matching, there no differences in the distribution of covariates between the treated and control groups for the two parts of reform. Secondly, you may find that Mean bias is $13.9 \%$ before matching and $2.7 \%$ after matching for the whole sample used to estimate the impact of the WP-part of the reform. We observe the same for the Median Bias indicator, with a reduction from 9.1 to 1.9 after matching. Finally, The B-Rubin indicator equal to 20.6 after matching is below the maximum limit of 25 and the second indicator R-Rubin equal to 1.00 is within the range of 0.5 to 2 . Thus, all these tests confirm that the samples are sufficiently balanced after matching.

For the T-part of the reform, the estimates show that the standardized difference in bias before matching was $10.9 \%$, and will be reduced to $1.4 \%$ after matching.

The results of tests for baseline bias and sensitivity analysis after Kernel matching for both reform components for the whole sample are confirmed for men and women (Table 4). In summary, using the propensity score matching with kernel matching, the bias is significantly reduced.

Table 4: Balancing test and reduction bias before and after kernel matching

\begin{tabular}{|c|c|c|c|c|c|}
\hline Sample & Pseudo R2 & Mean Bias & Median Bias & B - Rubin & R - Rubin \\
\hline \multicolumn{6}{|c|}{ Waiting period part of the reform } \\
\hline \multicolumn{6}{|l|}{ All } \\
\hline Unmatched & 0.258 & 13.9 & 9.1 & $135.5^{*}$ & 1.09 \\
\hline Matched & 0.008 & 2.7 & 1.9 & 20.6 & 1.00 \\
\hline \multicolumn{6}{|l|}{ Men } \\
\hline Unmatched & 0.272 & 14.4 & 7.2 & $141.1^{*}$ & 1.35 \\
\hline Matched & 0.011 & 2.5 & 1.3 & 24.7 & 1.06 \\
\hline \multicolumn{6}{|l|}{ Women } \\
\hline Unmatched & 0.280 & 13.3 & 6.0 & $141.7 *$ & 0.96 \\
\hline Matched & 0.018 & 2.6 & 1.8 & 24.8 & 0.96 \\
\hline \multicolumn{6}{|c|}{ Tenure part of the reform } \\
\hline \multicolumn{6}{|l|}{ All } \\
\hline Unmatched & 0.194 & 10.9 & 4.9 & $114.7^{*}$ & 0.70 \\
\hline Matched & 0.003 & 1.4 & 0.7 & 12.5 & 0.95 \\
\hline \multicolumn{6}{|l|}{ Men } \\
\hline Unmatched & 0.225 & 12.8 & 6.4 & $127.9 *$ & 0.68 \\
\hline Matched & 0.005 & 1.9 & 1.1 & 17.3 & 0.93 \\
\hline \multicolumn{6}{|l|}{ Women } \\
\hline Unmatched & 0.169 & 9.0 & 5.3 & $104.9 *$ & 0.96 \\
\hline Matched & 0.002 & 1.2 & 0.8 & 9.6 & 1.02 \\
\hline \multicolumn{6}{|c|}{$\begin{array}{l}\text { Note: Pseudo-R2 is obtained from probit estimation of the conditional treatment probability (propensity score) on all } \\
\text { the variables. }\end{array}$} \\
\hline \multicolumn{6}{|c|}{$\begin{array}{l}\text { The mean and median bias as summary indicators of the distribution of the absolute standardised percentage bias. } \\
\text { B-Rubin is the absolute standardized difference of the means of the linear index of the propensity score in the treated } \\
\text { and (matched) non-treated group. }\end{array}$} \\
\hline \multicolumn{6}{|c|}{ R-Rubin is the ratio of treated to (matched) non-treated variances of the propensity score index. } \\
\hline \multicolumn{6}{|c|}{$\begin{array}{l}\text { Rubin (2001) recommends that B be less than } 25 \text { and that } \mathrm{R} \text { be between } 0.5 \text { and } 2 \text { for the samples to be considered } \\
\text { sufficiently balanced. }\end{array}$} \\
\hline \multicolumn{6}{|c|}{ *An asterisk is displayed next to B and $\mathrm{R}$ values that fall outside those limits. } \\
\hline \multicolumn{6}{|c|}{ Source: Panel Hygie 2006-2010 and CBA database compiled by authors. } \\
\hline
\end{tabular}


Tables A1 and A2 in appendix display the descriptive statistics of individual characteristics for the treatment and control groups before and after matching for the tenure and the waiting period reforms respectively. The fourth and eighth columns of the two tables show the indicator of the matching quality which is the standardised percentage bias before and after matching, while the tenth column shows the value of total percentage bias reduction obtained after Kernel matching. For each covariate, the standardised bias is defined as the difference of sample means between the treated and control groups as a percentage of the square root of the average of the sample variances for the two groups (Rosenbaum, and Rubin, 1985). The fifth and ninth columns show the p-value test of mean difference for all variables between the treated and control groups, before and after kernel matching respectively.

The analysis of table A1, relative to the T-part, shows a strong decrease in the absolute value of the standardised percentage bias after matching. This percentage is between before matching $0.4-54.9 \%$, before matching and between $0.1-8.6 \%$ after Kernel matching.

Table A2 reports the statistics results for the WP-part. The absolute value of the standardised percentage bias before matching for all variables varies between $0.4-52.6 \%$. On the other hand, this same percentage varies only between $0.1-8.9 \%$ after matching.

After kernel weighting, the mean of the majority of variables is balanced between the treated and the control groups (absolute standardised percentage bias value is less than $10 \%$ for all covariates). Some tests of mean difference have p-values below $5 \%$ or $1 \%$. This type of result has been justified in the literature by the large size of the database and the use of categorical variables (Austin, 2009).

\section{Compositional groups over time before and after matching}

The DID methods provides unbiased estimators if the trend assumption is verified and if the composition in the treatment and control groups is similar between the pre- and post-reform periods. If these conditions are not verified, the DID model combined with propensity score matching is commonly used to reduce this type of bias. Propensity scores are used to balance the treatment and control groups based on a set of observable characteristics in order to that the composition of the groups does not change over time (Rosenbaum, and Rubin, 1985; Stuart et al. 2014).

Note, for the T-part of reform, the treatment and control groups do not contain the same individuals before and after the reform, and we therefore adopt a pseudo-panel approach for this part of reform. Thus, the matching allows to reduce the potential heterogeneity of treatment and control groups.

Tables A3 and A4 in appendix display the analyses for the two parts of the reform. The results show that propensity score with Kernel matching reduces the compositional changes in the groups over time. For the T-part, we note that for the control group after matching, the distribution of age, salary, and the means of health indicators are similar before and after the reform (Table A3). For example, before matching and for the control group, the frequency of the $25-35$ age group is $47 \%$ in pre-reform and $28 \%$ 
in post-reform. After matching, this gap is reduced from $21 \%$ in pre-reform to $17 \%$ in post-reform. The same conclusion is confirmed for the WP-part of the reform, where the matching allows us to obtain a homogeneous composition of the treatment and control groups over time (Table A4).

\section{RESULTS}

In the rest of the paper, we prefer the DID approach with matching because we observe significant statistical differences between the control and the treated groups. The characteristics of the groups also change over time, particularly in the case of the T-part of the reform. This is because groups are defined by a criterion of seniority and seniority increases mechanically over time, so that groups do not include the same individuals from one period to the next. For these reasons, the DID matching approach seems appropriate because it reduces the statistical differences that exist between the control and the treated groups, both before and after the reform. Table 4 confirms the contribution of matching, which makes it possible to statistically reconcile the treated and control samples. Our DID estimates without matching (Table 5, column 1 and 2) also justify this choice because, although the estimated parameters go in the same direction, the absence of matching reduces the significance of certain estimates.

\section{Impact of the WP-part of the reform: reduction of waiting period}

To estimate the impact of the first part of the reform, the reduction of the waiting period, we used a DID method with matching. The so-called Treated group 1 was compared to Control group 1 which includes employees with a lower level of sick leave compensation, with no complementary benefit during the first three days of sick leave.

Estimations were also run separately for men and women. Table 5 shows the results related to the WPpart of the reform. Globally, taking Control 1 as reference group, the WP-part of the reform had a positive and significant effect on the number of sick days ( +0.5 days). Estimates are positive and significant for men (+ 1.3 days) and non-significant for women. Compared to Control group 1, the WPpart of the reform increased slightly but significantly the probability of sickness absence by $+1.3 \mathrm{pp}$ for men. The reforms do not have a significant effect on women's probability of sickness absence.

We note that the impact of the reduction of the waiting period on the number of sick days is higher for men. Men are more often absent from work for health reasons. Their absence behaviour also appears to correlate with sickness compensation level (Ben Halima and Koubi, 2018).

\section{Impact of the T-part of the reform: reduction of the minimum required tenure}

The aim of the reduction of the tenure requirement is to allow individuals with low seniority to be eligible for the higher complementary benefit after the reform. Treated group 2 are individuals with one 
and two years of tenure in 2007 and in 2009. Control group 2 incorporates all non-treated individuals, with tenure more than three years.

We start by estimating a DID model with matching for all samples, and we also estimate a model for men and women (Table 5). Taking Control group 2, extended access to complementary sickness benefits for all employees with over one year of tenure has a significant and positive effect: +0.6 days of sick leave and $+0.9 \mathrm{pp}$ on sickness probability.

Table 5 shows the results by gender. The second part of the reform has a higher and significant effect on the number of sick days for women only ( +1.7 days). We get the same results when looking at the effects of the T-part of the reform on the probability of sickness absence. Compared to Control group 2 the impact of the reform is significant and positive for women $(+3.4 \mathrm{pp})$. On the other hand, the reform does not have a significant impact on sickness probability for men.

Table 5: Difference in differences results before and after matching - Two parts of reform

\begin{tabular}{|c|c|c|c|c|c|c|c|}
\hline & & \multicolumn{2}{|c|}{$\begin{array}{l}\text { DID before matching and } \\
\text { without covariates } \\
\text { (1) }\end{array}$} & \multicolumn{2}{|c|}{$\begin{array}{l}\text { DID before matching and with } \\
\text { covariates } \\
\text { (2) }\end{array}$} & \multicolumn{2}{|c|}{$\begin{array}{c}\text { DID after matching and with } \\
\text { covariates } \\
\text { (3) }\end{array}$} \\
\hline \multicolumn{8}{|c|}{$\begin{array}{l}\text { Waiting period part of the reform } \\
(n=305,652)\end{array}$} \\
\hline \multirow{4}{*}{$\begin{array}{l}\text { Number of } \\
\text { sick days }\end{array}$} & & Estimates & $\mathrm{SE}$ & Estimates & SE & Estimates & $\mathrm{SE}$ \\
\hline & All & 0,106 & 0,110 & 0,107 & 0,345 & $0.482 * * * a$ & 0.113 \\
\hline & Men & 0,022 & 0,146 & 0,041 & 0,152 & $1.316 * * *$ & 0.148 \\
\hline & Women & 0,213 & 0,159 & 0,163 & 0,321 & 0.221 & 0.164 \\
\hline \multirow{3}{*}{$\begin{array}{l}\text { Probability } \\
\text { of sickness }\end{array}$} & All & $0,007 * *$ & 0,004 & $0,009 * *$ & 0,004 & 0.002 & 0.004 \\
\hline & Men & 0,006 & 0,005 & $0,010 *$ & 0,005 & $0.013 * *$ & 0.005 \\
\hline & Women & $0,008 *$ & 0,005 & 0,007 & 0,005 & 0.001 & 0.005 \\
\hline \multicolumn{8}{|c|}{$\begin{array}{l}\text { Tenure part of the reform } \\
(n=123,370)\end{array}$} \\
\hline \multirow{4}{*}{$\begin{array}{l}\text { Number of } \\
\text { sick days }\end{array}$} & & Estimates & SE & Estimates & SE & Estimates & $\mathrm{SE}$ \\
\hline & All & $0,252 *$ & 0,129 & 0,222 & 0,137 & $0.646 * * *$ & 0.154 \\
\hline & Men & 0,063 & 0,176 & 0,012 & 0,191 & 0.116 & 0.174 \\
\hline & Women & $0,447 * *$ & 0,187 & $0,361^{*}$ & 0,197 & $1.740 * * *$ & 0.214 \\
\hline \multirow{3}{*}{$\begin{array}{l}\text { Probability } \\
\text { of sickness }\end{array}$} & All & 0,000 & 0,004 & 0,001 & 0,004 & 0.009* & 0.005 \\
\hline & Men & $-0,004$ & 0,006 & $-0,004$ & 0,006 & -0.005 & 0.006 \\
\hline & Women & 0,005 & 0,006 & 0,000 & 0,006 & $0.034 * * *$ & 0.007 \\
\hline
\end{tabular}

Note: This table shows the DID before-after matching estimates and with-without control variables. The significant coefficients are in bold. Vector of covariates contains gender, age, department of residence, region, socio-professional category, salary, previous health indicators approximated by the number of visits to a general and specialist practitioner and number of days of hospitalization, company size and sector, and the regional unemployment rate.

Reading example ${ }^{\mathrm{a}}$ : the first part of the reform "reduction of the waiting period from 10 days to 7 days" has a significant and positive impact on the number of annual sickness absences of 0.5 days for all employees.

$*, * *, * *$ Significant at $10 \%, 5 \%$, and $1 \%$ respectively.

Source: Panel Hygie 2006-2010 and CBA database compiled by authors. 


\section{Robustness checks: Placebo regressions}

We run Placebo regressions to test the robustness of our estimates. The main assumption is the common trend assumption: the behaviour of the treated group and the control group is assumed to be the same in the absence of a reform. We estimate Placebo regressions between 2005 and 2007, period with no sick leave reform.

There is no treatment within this time frame and so we expect DID estimates not to be significant. If they are not, the common trend assumption will be more credible. However, the economic crisis began in 2008 and it can have an impact in sickness absence. The crisis only started to take effect in France only in 2009, so the economic crisis effect is excluded from a Placebo regression. Concerning the WPpart of the reform and the T-part of the reform, the overall Placebo regressions show that the estimated parameters are not significant, neither on the number of sick days or sickness probability.

\section{DISCUSSION}

In this paper, we examine two folds of the 2008 ANI reform in the private sector in France that modified important parameters of the complementary benefit paid by the employer.

In this paper, we examine two folds of the 2008 ANI reform in the private sector in France that modified important parameters of the complementary benefit paid by the employer.

The WP-part of the reform, reduction of the waiting period from 10 to 7 days, significantly increases the annual average number of sick days ( +0.5 days). The T-part of the reform relaxed the seniority requirement for eligibility to the complementary benefit. The minimum tenure requirement was set to 1 year instead of 3 years before the reform. The T-part of the reform concerned a smaller group but had a bigger impact ( +0.6 days on the number of sick days and $+0.9 \mathrm{pp}$ on sickness probability), than the WP-part of the reform. This study also demonstrates that men reacted differently from women to the reform. The WP-part of the reform significantly increased the annual number of sick leave days and the frequency of sick leave for men, while the T-part of the reform has significant impact only for women. The paper confirms previous results obtained in literature that assess the changes in benefit levels on sick leave behaviour (Henrekson and Persson, 2004; Ziebarth and Karlsson, 2014; Pettersson-Lidbom et al., 2013).

In the present case, two changes in the complementary benefit paid by the employer are assessed: firstly, the effect of being eligible (extensive margin) and secondly a change in the waiting period (intensive margin).

The paper addresses the lack of information available on the complementary benefit by documenting a great deal of CBAs' settings. As a result, we confirm that differences in CBAs' settings are a source of great heterogeneity in the indemnification of workers in the French private sector. Older articles dealing with the French sick leave system don't take into account the complementary benefit and thus miss that 
great source of heterogeneity among French workers. Instead, the convey a false representation of an egalitarian system, a view focused on the social security part of the system. This article, by documenting the Private sector system, also paves the way to a documented comparison between the private sector and the public sector sick leave systems, the latter being much simpler and uniform.

These results have several important implications for public policy. First, the paper reassesses the role of compensation for private sector employers, with consequences for labour costs (via the employer's complementary benefits) and for public finances (via the change in behaviour induced by the choice of the minimum compensation level, which also affects the Social security compensation). This knowledge will help policymakers to adapt the design of the complementary benefit (and its minimal requirements) more accurately and consequently manage both the budgetary objectives and aims in terms of equity between workers.

Finally, the paper sheds light on two issues related to population ageing that have to be addressed in order to maintain competitiveness. One issue is the growth of sick leave expenses and was mentioned in the introduction. Another issue is the necessary increase of the labour force participation rate, particularly for underrepresented groups - such as of women. Generally, in the labour supply literature, one typically finds that women have much larger elasticities than men. The more specific literature on sick leave is much less conclusive, suggesting that things are not that simple. For example, Ziebarth and Karlsson (2014) finds that women are less sensitive than men to sick leave compensation, while De Paola et al. (2014) and Henrekson and Persson (2004) finds the opposite and Pettersson-Lidbom et al. (2013) find no difference. In this paper we find that women's behaviour responds more strongly than men when the change in compensation is higher (T-part of the reform) and less strongly when the change is lower (WP-part of the reform), suggesting that differences in elasticities for women and men depend on the intensity of the reform. But this question remains mainly unsolved and requires further investigations.

\section{CONCLUSION}

The results of this study shed light on the important role of the complementary benefit in sickness absence compensation in the French private sector. This benefit comes in addition to social security compensation. It is paid by the employer according to rules defined at the CBA level, with the obligation of meeting some legal minimam requirements. Our results document the key role played by the complementary benefit in the sickness absence compensation system, assess the impact of the 2008 reform that enlarged and enhanced the complementary benefit legal minimal parameters, and show its influence on worker's sickness absence behaviour.

These findings point out the need for simplification, standardization and transparency in the regulation of the French sick leave system. Extending this modernization path after the 2008 reform, would have 
several advantages like reducing inequalities between workers, improving the transparency and governance of the sick leave system, and better including certain populations, especially employees with little seniority and women. The French system would also gain a better harmonization with a large number of developed countries having simpler and more efficient systems (Ziebarth and Karlsson, 2014; Henrekson and Persson, 2004) and also with the public sector. The reform would also be favorable to women, who more often than men hold insecure jobs and are therefore on average less well compensated during sickness absence. 


\section{REFERENCES}

Aaviksoo E., Kiivet RA., Influence of the sickness benefit reform on sickness absence. Health Policy, 120 (9):1070-1078, 2016.

Afsa C., Givord P., Le rôle des conditions de travail dans les absences pour maladie : le cas des horaires irréguliers", Économie et Prévision, n 187, pp. 83-103, 2009.

Allen S.G., An Empirical Model of Work Attendance. Review of Economics and Statistics 63:77-87, 1981.

Austin, P.C. Balance Diagnostics for Comparing the Distribution of Baseline Covariates Between Treatment Groups in Propensity Score Matched Samples. Statistics in Medicine 28(25), 3083-3107, 2009.

Barmby T., Orme C. and Treble J. Worker absence histories: a panel data study. Labour Economics, 2: 53-65, 1995.

Ben Halima M.A., Debrand T., and Regaert C., Comprendre les disparités des arrêts maladie selon les départements, Revue française d'économie, Vol. 26, p. 121-159. (4, 18), 2012.

Ben Halima M.A., Koubi M., Regaert C., The Effects of the Complementary compensation on Sickness absence: an Approach Based on Collective Bargaining Agreements in France. LABOUR: Review of Labour Economics and Industrial Relations 32 (3): 353-394, 2018.

De Paola M., Scoppa V. and Pupo V., Absenteeism in the Italian Public Sector: The Effects of Changes in Sick Leave Policy. Journal of Labor Economics 32(2): 337-360, 2014.

Frick B., Malo M.A., Labour Market Institutions and Individual Absenteeism in the European Union: The Relative Importance of Sickness Benefit Systems and Employment Protection Legislation, Industrial Relations. A Journal of Economy and Society 47 (4): 505-529, 2008.

Galizzi M. and Boden L.I., The Return to Work of Injured Workers: Evidence from Matched Unemployment Insurance and Workers' Compensation Data," Labour Economics, Vol. 10, p. 311337. (4), 2003.

Grignon M._and Renaud T.,_Moral Hazard, Doctors and Absenteism in France. Preliminary Analysis Based on Aggregate Data, Revue d'Epidémiologie et de Santé Publique, vol. 55, p. 243-251.(4), 2007

Henrekson M. and Persson M., The effects on sick leave of changes in the sickness insurance system. Journal of Labor Economics 22: 87-113, 2004.

Jauneau Y. and Vidalenc J., Une photographie du marché du travail en 2018, Insee première 1740, 2019.

Ose S., Working Conditions, Compensation and Absenteeism, Journal of Health Economics, Vol. 24, p. 161-188. (4, 18), 2005.

Pettersson-Lidbom P., Skogman Thoursie P., Temporary Disability Insurance and Labor Supply: Evidence from a Natural Experiment. The Scandinavian Journal of Economics 115(2): 485-507, 2013.

Puhani P., Sonderhof K., The effects of a sick pay reform on absence and on health-related outcomes. Journal of Health Economics 29 (2) : 285-302, 2010. 
Rosenbaum, P.R. and Rubin, D.B. Constructing a Control Group Using Multivariate Matched Sampling Methods that Incorporate the Propensity Score. The American Statistician 39(1), 3338,1985 .

Rubin, D.B. Using Propensity Scores to Help Design Observational Studies: Application to the Tobacco Litigation. Health Services \& Outcomes Research Methodology 2, 169-188, 2001

Shapiro C. and Stiglitz J., Equilibrium Unemployment as a Worker Discipline Device”, The American Economic Review, 74 (3), pp.433-444, 1984.

Stuart E.A., Huskamp H.A., Duckworth K., Simmons J., Song Z., Chernew M.E., Barry C.L. Using propensity scores in difference-in-differences models to estimate the effect of a policy change. Health Services and Outcomes Research Methodology 14,166-182, 2014.

Ziebarth N. R., Karlsson M., A natural experiment on sick pay cuts, sickness absence, and labor costs. Journal of Public Economics 94 (11-12): 1108-1122, 2010.

Ziebarth N. R., Karlsson, M., The effects of expanding the generosity of the statutory sickness insurance system. Journal of Applied Econometrics 29(2): 208-230, 2014. 


\section{Appendix 1: The French sick pay system ${ }^{4}$}

In France, the sickness insurance system that aims to replace an employee's wage during her absence due to illness is multi-tiered. This appendix describes the first, universal tier. It includes daily sickness benefits that are paid by the National Health Insurance Fund and supplementary benefits that are paid by the employer.

The General Health Insurance scheme provides the payment of daily sickness benefits from the 4th day following the medical intervention that prescribes sick leave. This daily allowance corresponds to $50 \%$ of the employee's gross daily income for a maximum duration of three years (within a 360-day limit). The wage base that is used to calculate daily sickness benefits is limited to $1 / 720^{\text {th }}$ of the annual Social Security ceiling for the period under study. This ceiling was amended to $1 / 730^{\text {th }}$ of the annual Social Security ceiling (reassessed on January 1st of each year) from December $10^{\text {th }}, 2010$ (Circular of November $25^{\text {th }}, 2010$, relative to certain modes of calculating daily benefits), then to 1.8 times the minimum wage (SMIC) as of the $1^{\text {st }}$ of January, 2012 (Decree no. 2011-1957 of December $26^{\text {th }}, 2011$, relative to the modes of allocating daily sickness benefits entitled under the health insurance system). This change limited the daily benefit to $41.38 €$ on January 1 st, 2012.

Eligibility for daily sickness benefits is subject to not only registration under the compulsory national health insurance scheme but also to a minimum contribution rate that is equivalent to 200 hours worked over the previous three months or 800 hours over a year. The conditions under which daily sickness benefits are allocated are expressed in the number of hours that are worked. They can also be expressed as equivalent wages subject to social security contributions, which is 1,015 times the hourly minimum wage over the last six months for 200 hours and 2,030 times the hourly minimum wage over the last 12 months for 800 hours. The calculation of daily sickness benefits is based on earnings during the three months preceding the sick leave spell.

A percentage of the working population does not benefit from coverage against the risk of sickness absence, specifically, workers who have not worked 200 hours over the course of the previous three months (or paid contributions equivalent to 1,015 times the hourly minimum wage over the course of the last six months) and do not meet the conditions of eligibility for daily sickness benefits. This mobile population in precarious employment has not yet been estimated, although the situation in the job market and the resulting increase in the number of employment gaps in individuals' career paths tend to aggravate this type of situation.

The employer is legally obliged to supplement, under certain conditions subject to a waiting period, the benefits that are paid by the health insurance scheme. Prior to the passage of the law of 2008, benefits were paid at the latest from the 11th day of sick leave. Following this reform, they were paid at the latest from the 8th day. It aims to reach a global replacement rate of $90 \%$ over at least 30 days. In the event of successive work absences over a period of 12 months, the total duration of benefits is limited to the maximum duration. These benefits are increased according to the number of years of service. The conditions for eligibility and the waiting period were amended by Law no. 2008-596 on June 25, 2008, 'concerning the modernization of the labor market.' The employee must justify a minimum number of years' service in the employing company or establishment (3 years until June 26, 2008, reduced to 1 year by Law no. 2008-596 of June 25, 2008, 'concerning the modernization of the labor market'). Furthermore, supplementary benefits do not apply to employees who work from home, seasonal workers, casual or temporary employees.

\footnotetext{
${ }^{4}$ Source : $\underline{\text { http://vosdroits.service-public.fr/F3053.xhtml }}$
} 
Fig. A1. Time trends absence before matching for the both part of reforms in 2006-2010: analysis for men
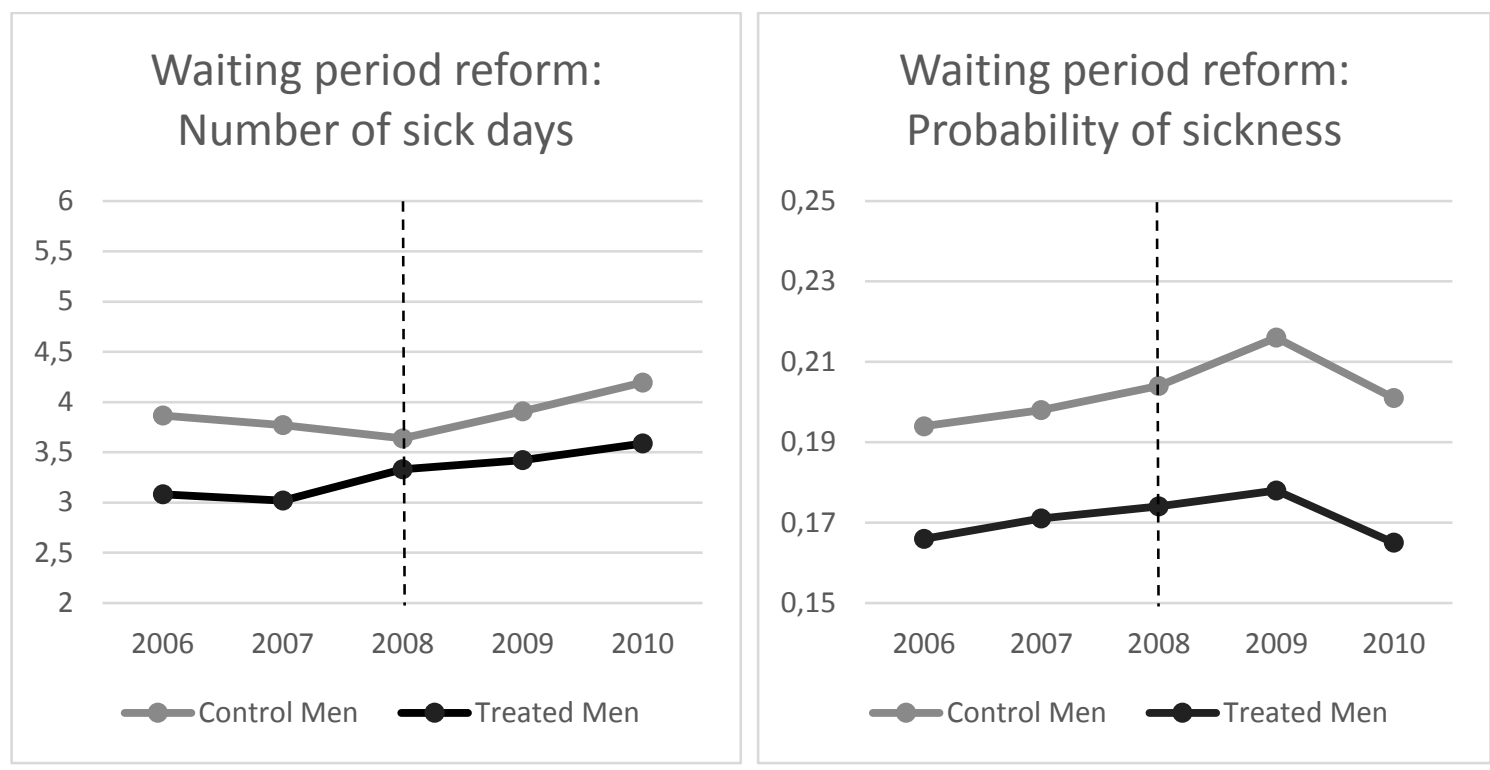

Common Trends Test: 0.212

P-value : 0.645

Common Trends Test: 2.98

P-value : 0.124
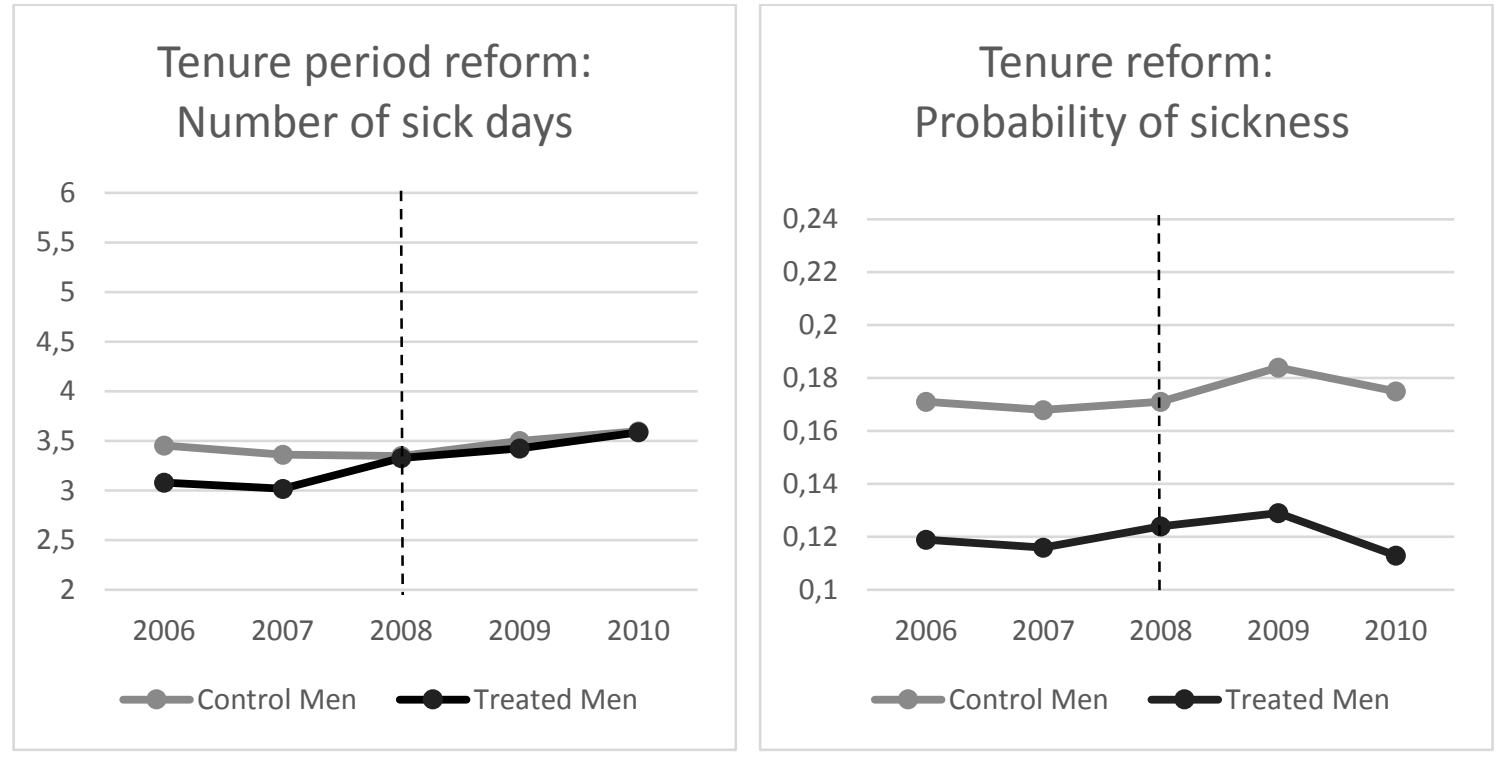

Common Trends Test: 0.077

Common Trends Test: 0.237

P-value : 0.781

P-value : 0.626

* The test statistic on the common dynamics trend is the Wald test of the joint significance of all pre-treatment. The p-value for the Wald test is greater than 0.05 confirm the common trend pre-treatment assumption.

Source: Panel Hygie 2006-2010 and CBA database compiled by authors. 
Fig. A2. Time trends absence before matching for the both part of reforms in 2006-2010: analysis for women

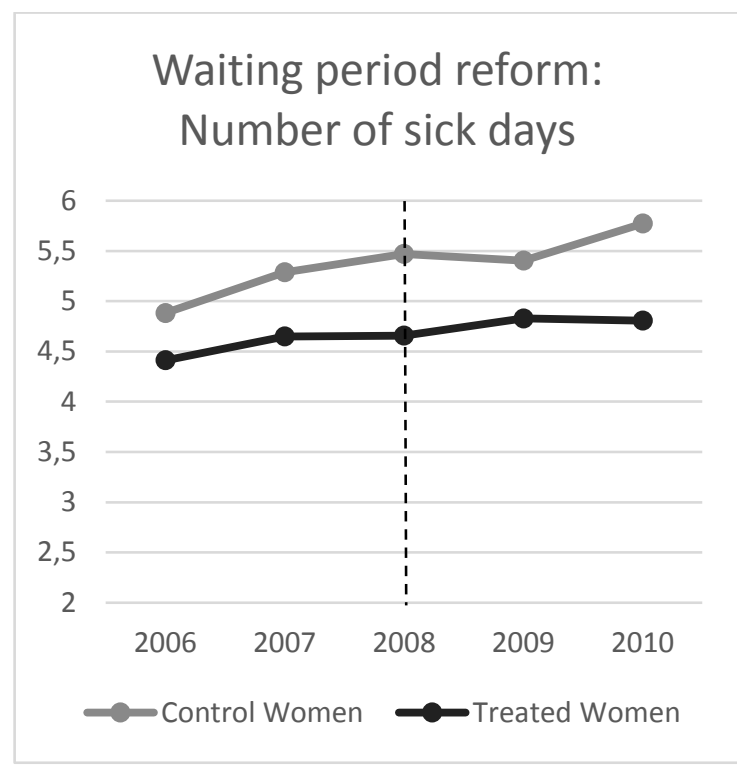

Common Trends Test: 0.011

P-value : 0.913

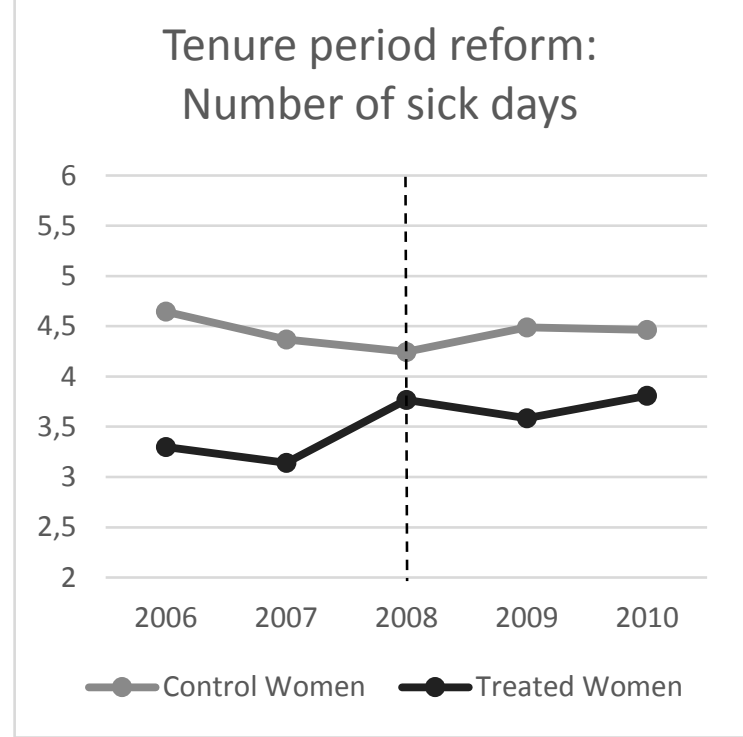

Common Trends Test: 0.942

P-value : 0.331

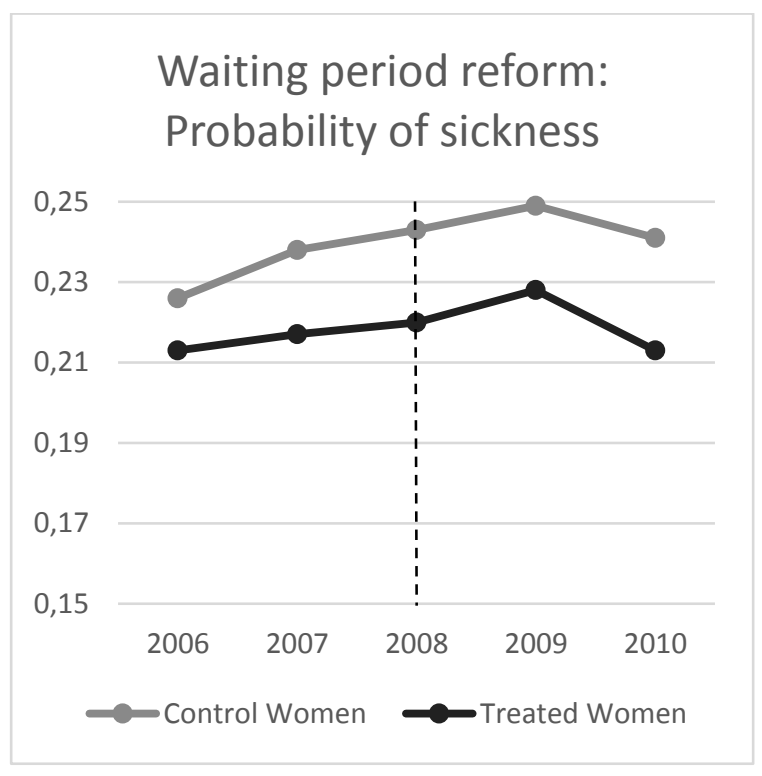

Common Trends Test: 0.309 P-value : 0.578

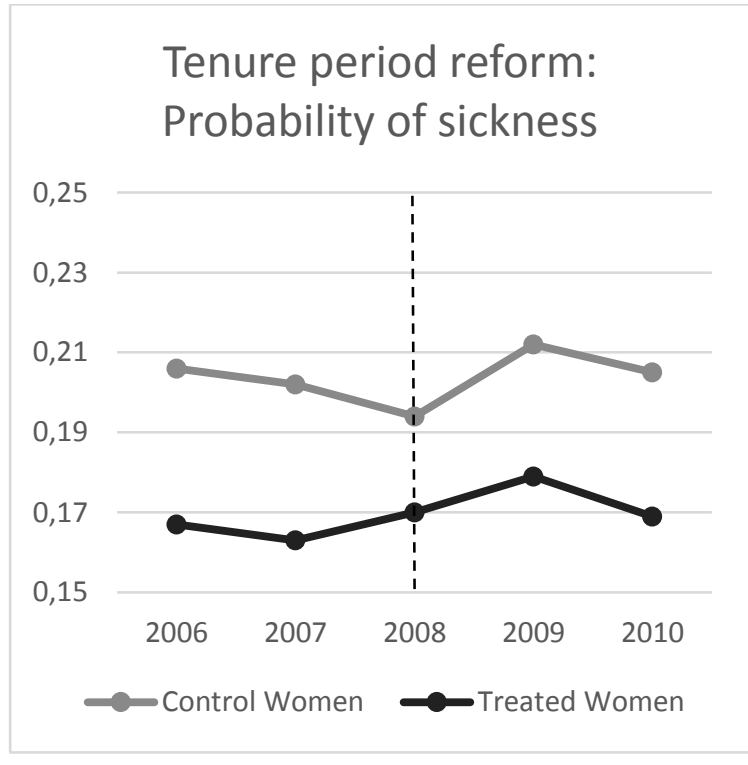

Common Trends Test: 0.817

P-value : 0.366

* The test statistic on the common dynamics trend is the Wald test of the joint significance of all pre-treatment. The p-value for the Wald test is greater than 0.05 confirm the common trend pre-treatment assumption.

Source: Panel Hygie 2006-2010 and CBA database compiled by authors. 
Fig. A3. Time trends absence after matching for the both part of reforms in 2006-2010: analysis for all individuals

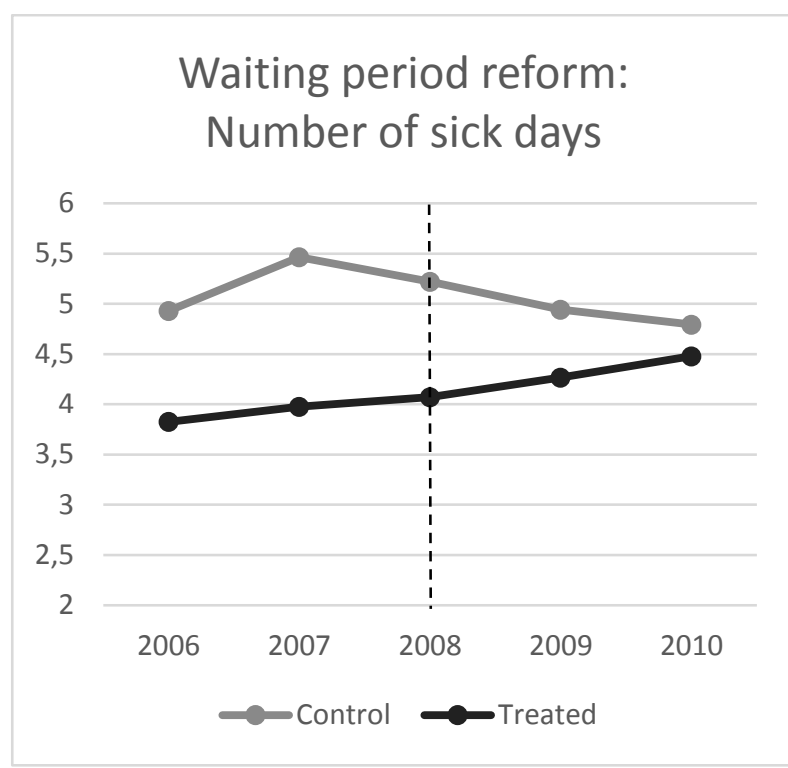

Common Trends Test: 0.042

P-value : 0.8366

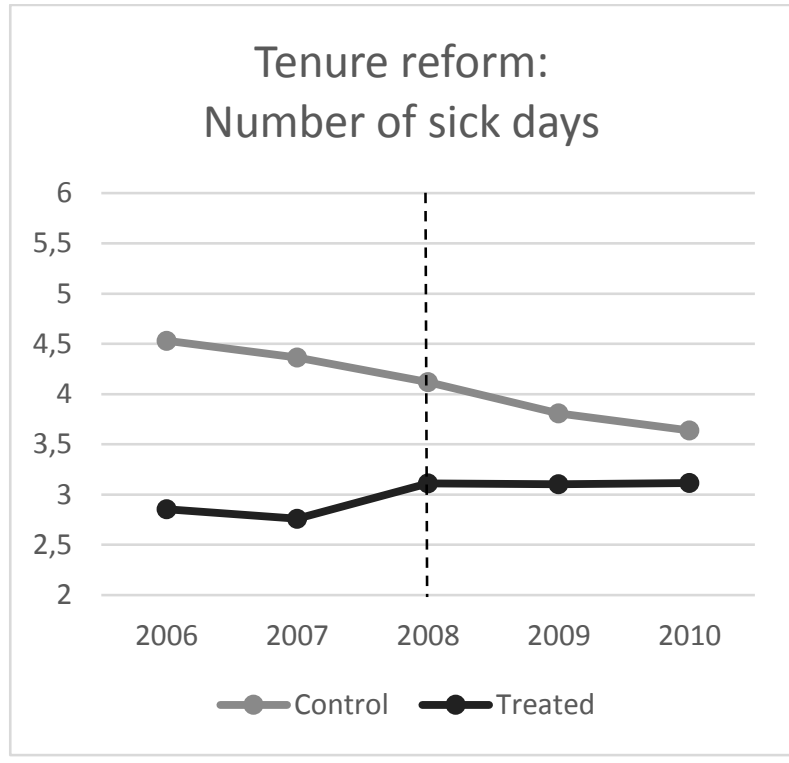

Common Trends Test: 0.122

P-value : 0.726

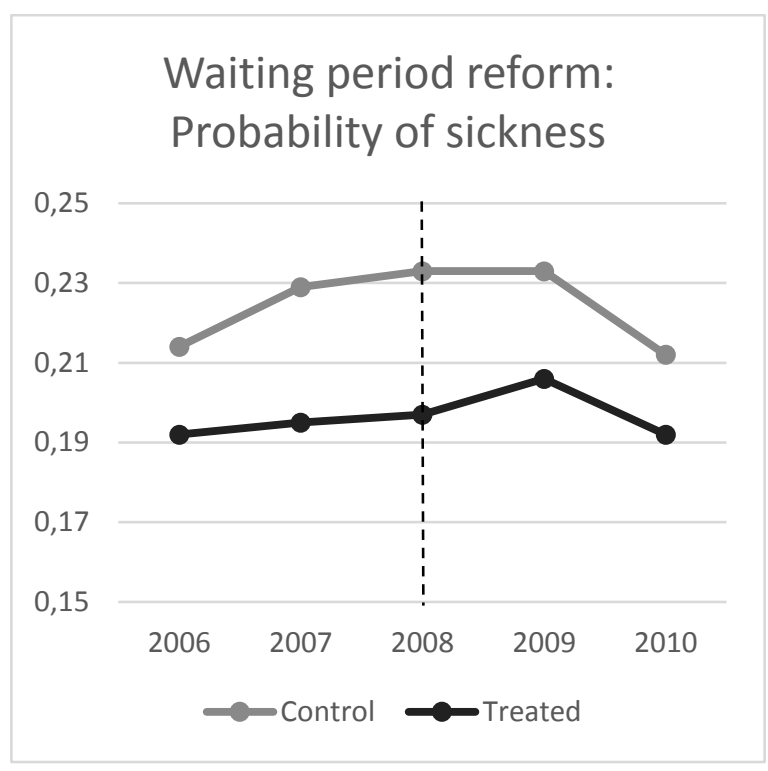

Common Trends Test: 1.550

P-value : 0.213

\section{Tenure period reform: \\ Probability of sickness}

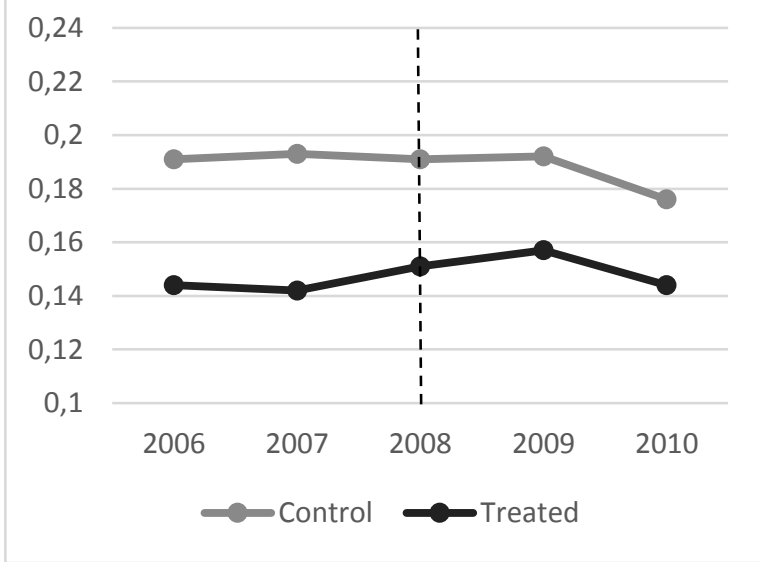

Common Trends Test: 0.049

P-value : 0.823

* The test statistic on the common dynamics trend is the Wald test of the joint significance of all pre-treatment. The p-value for the Wald test is greater than 0.05 confirm the common trend pre-treatment assumption.

Source: Panel Hygie 2006-2010 and CBA database compiled by authors. 
Fig. A4. Time trends absence after matching for the both part of reforms in 2006-2010: analysis for men

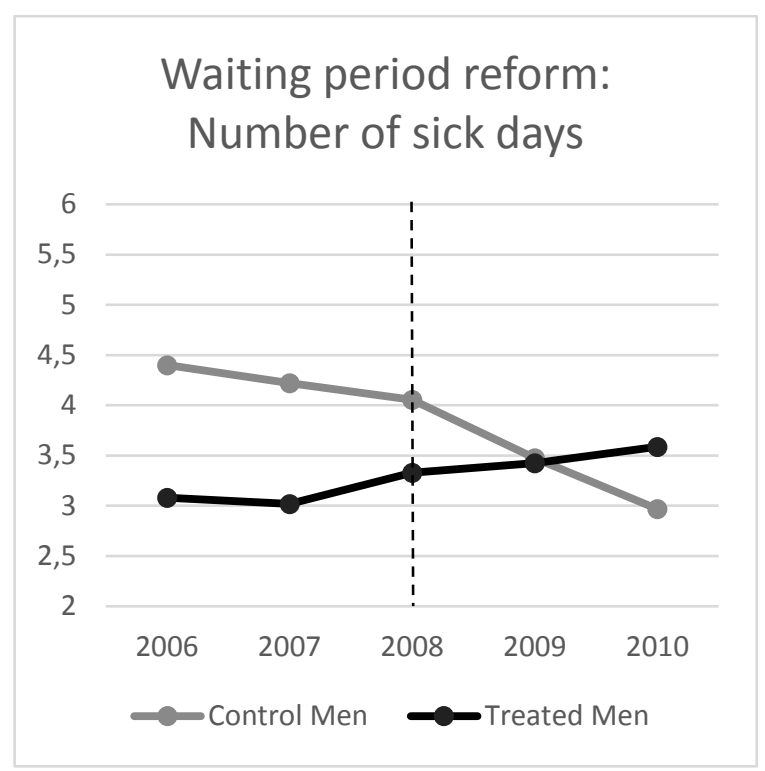

Common Trends Test: 0.365

P-value :0.545

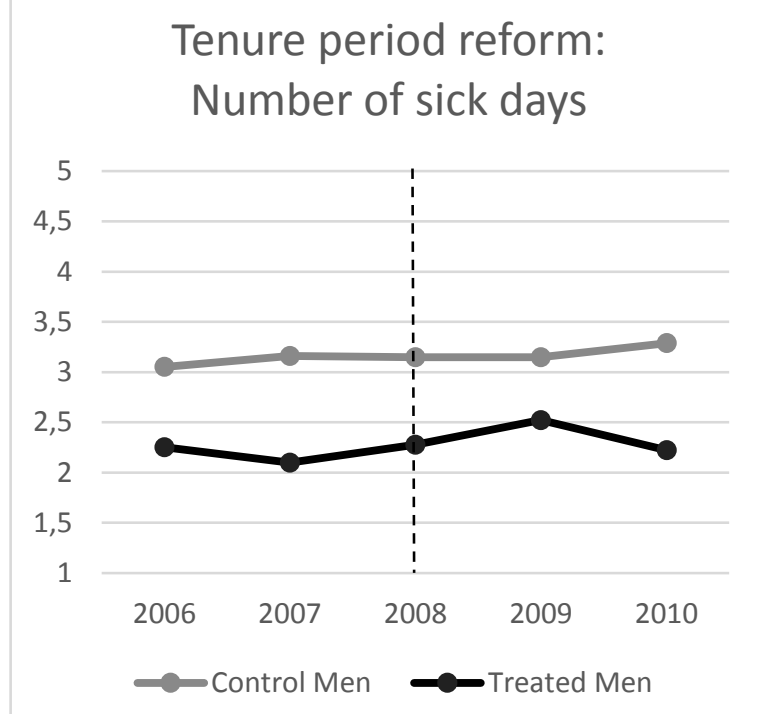

Common Trends Test: 0.176

P-value : 0.674

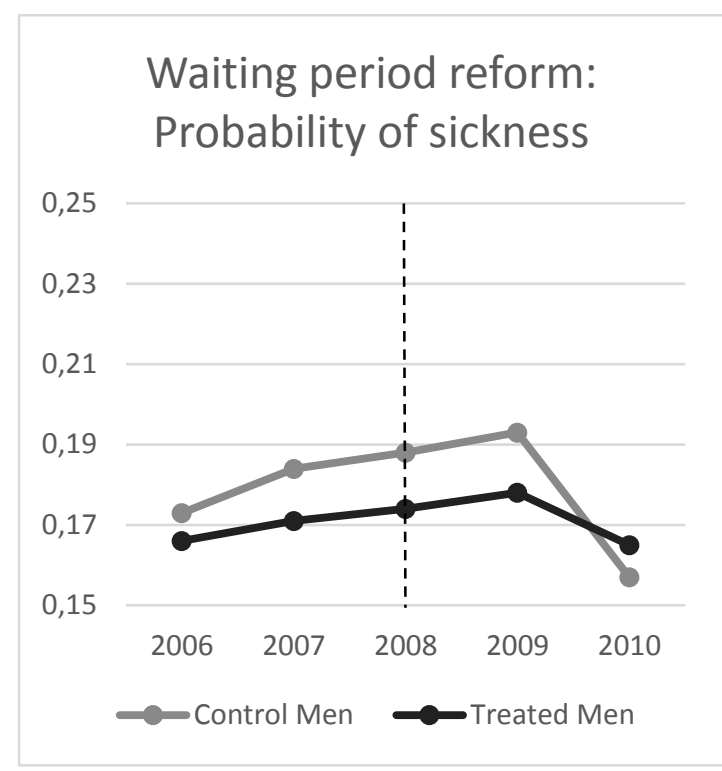

Common Trends Test: 0.603

P-value : 0.437

\section{Tenure period reform: \\ Probability of sickness}

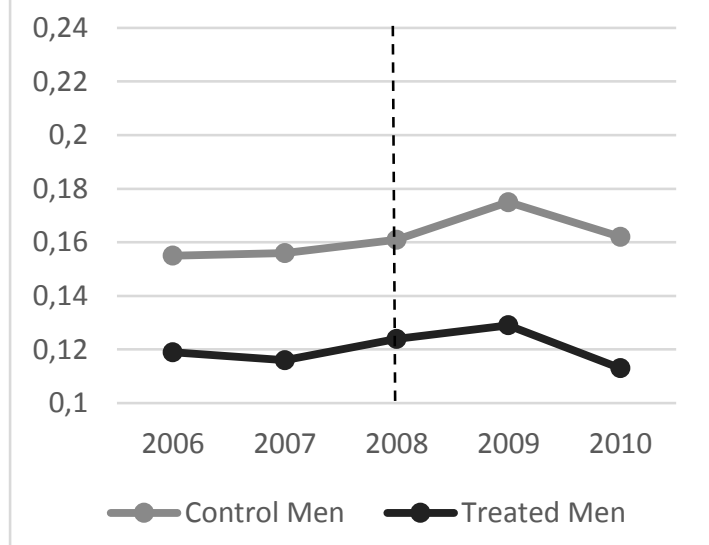

Common Trends Test: 1.023

P-value : 0.311

* The test statistic on the common dynamics trend is the Wald test of the joint significance of all pre-treatment. The p-value for the Wald test is greater than 0.05 confirm the common trend pre-treatment assumption.

Source: Panel Hygie 2006-2010 and CBA database compiled by authors. 
Fig. A5. Time trends absence after matching for the both part of reforms in 2006-2010: analysis for women

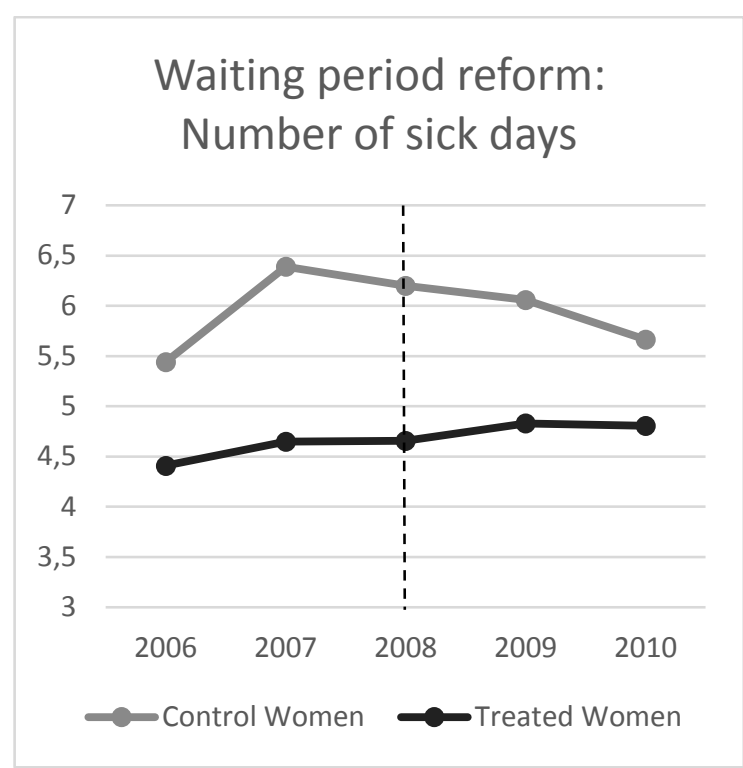

Common Trends Test: 0.555

P-value :0.456

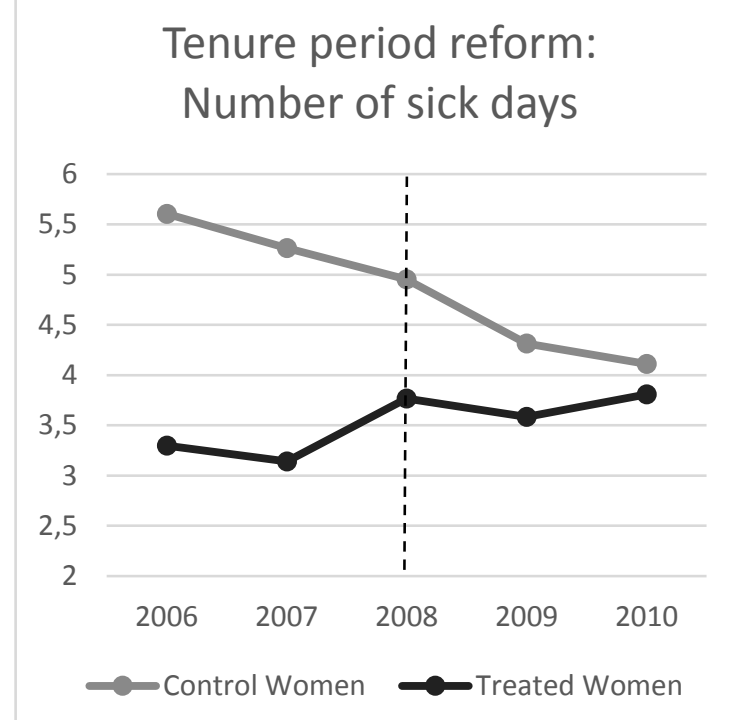

Common Trends Test: 0.697

P-value : 0.403

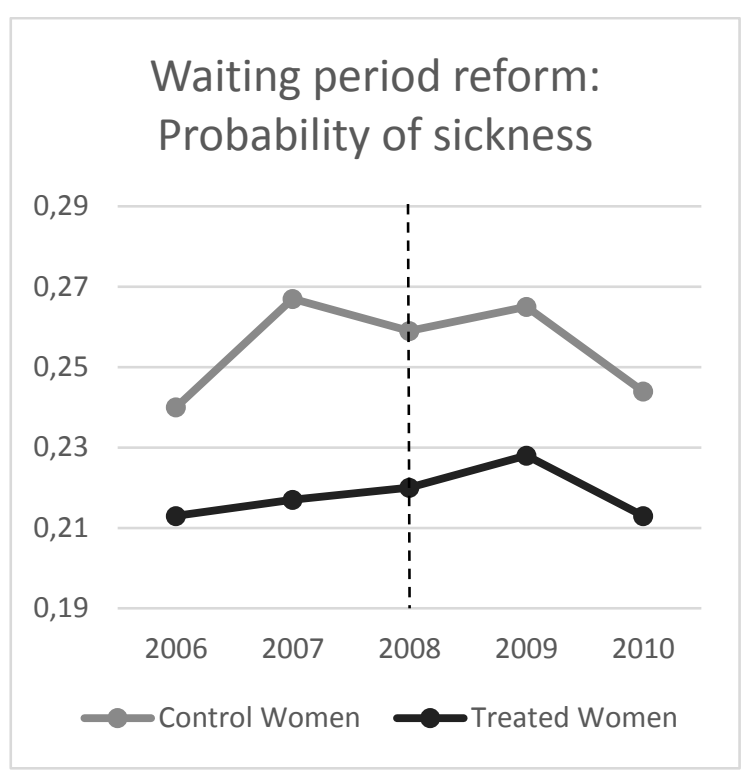

Common Trends Test: 0.981

P-value :0.321

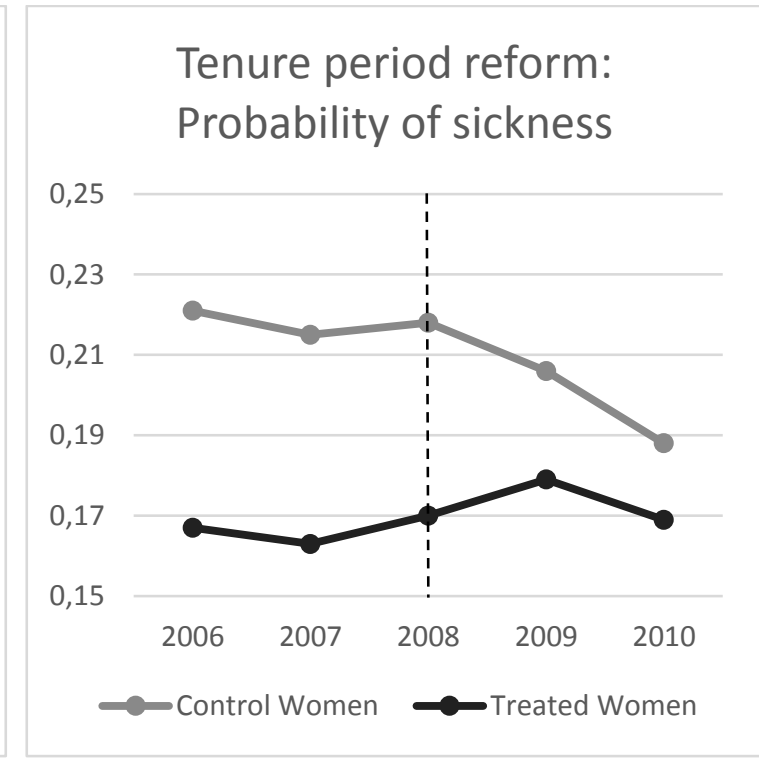

Common Trends Test: 0.268

P-value : 0.604

* The test statistic on the common dynamics trend is the Wald test of the joint significance of all pre-treatment. The p-value for the Wald test is less than 0.05 confirm the common trend pre-treatment assumption.

Source: Panel Hygie 2006-2010 and CBA database compiled by authors. 
Table A1: Covariate balance across Treated and Control groups before and after Matching: Tenure part of the reform

\begin{tabular}{|c|c|c|c|c|c|c|c|c|c|}
\hline \multirow[b]{2}{*}{ Variable } & \multicolumn{4}{|c|}{ Before matching } & \multicolumn{3}{|c|}{ After matching } & \multirow[b]{2}{*}{$p>t$} & \multirow[b]{2}{*}{$\begin{array}{c}\text { \%reduction } \\
\text { bias }\end{array}$} \\
\hline & Treated & Control & \%bias & $p>t$ & Treated & Control & \%bias & & \\
\hline Women & 0,57 & 0,49 & 15.8 & 0.000 & 0,58 & 0,60 & -4.6 & 0.000 & 71.0 \\
\hline Age $[25 ; 35]$ & 0,44 & 0,20 & 53.5 & 0.000 & 0,44 & 0,47 & -6.1 & 0.000 & 88.6 \\
\hline Age $[36 ; 45]$ & 0,29 & 0,32 & -6.0 & 0.000 & 0,29 & 0,28 & 1.2 & 0.059 & 80.3 \\
\hline Age $[46 ; 55]$ & 0,18 & 0,32 & -32.6 & 0.000 & 0,18 & 0,18 & -0.2 & 0.781 & 99.5 \\
\hline Age $[56 ; 65]$ & 0,06 & 0,16 & -34.0 & 0.000 & 0,06 & 0,06 & -0.5 & 0.264 & 98.4 \\
\hline Q1 salary & 0,51 & 0,26 & 52.2 & 0.000 & 0,52 & 0,52 & -0.1 & 0.980 & 100.0 \\
\hline Q2 salary & 0,23 & 0,23 & 0.4 & 0.434 & 0,23 & 0,23 & 0.4 & 0.528 & -3.6 \\
\hline Q3 salary & 0,14 & 0,27 & -30.7 & 0.000 & 0,14 & 0,13 & 2.3 & 0.000 & 92.5 \\
\hline Q4 salary & 0,12 & 0,24 & -33.2 & 0.000 & 0,11 & 0,12 & -2.9 & 0.000 & 91.4 \\
\hline Employee & 0,52 & 0,46 & 11.8 & 0.000 & 0,52 & 0,54 & -5.4 & 0.000 & 53.8 \\
\hline Laborer & 0,14 & 0,26 & -28.6 & 0.000 & 0,14 & 0,12 & 5.1 & 0.000 & 82.2 \\
\hline Supervisor & 0,09 & 0,09 & 1.6 & 0.001 & 0,09 & 0,09 & 2.9 & 0.000 & -78.5 \\
\hline Executive & 0,19 & 0,15 & 12.5 & 0.000 & 0,20 & 0,18 & 4.1 & 0.000 & 66.9 \\
\hline $\begin{array}{l}\text { Number of GP consultations } \\
\text { the previous year }\end{array}$ & 3,80 & 3,90 & -1.8 & 0.000 & 3,81 & 3,76 & 0.9 & 0.164 & 51.7 \\
\hline $\begin{array}{l}\text { Number of specialist consultations } \\
\text { the previous year }\end{array}$ & 2,26 & 2,16 & 1.8 & 0.000 & 2,33 & 2,37 & -0.8 & 0.226 & 53.6 \\
\hline Number of days in hospital the previous year & 0,69 & 0,12 & 7.6 & 0.000 & 0,77 & 0,13 & 8.6 & 0.000 & -12.3 \\
\hline Chronic disease -Diabetes & 0,01 & 0,02 & -7.8 & 0.000 & 0,01 & 0,01 & -0.5 & 0.330 & 93.3 \\
\hline Chronic disease - Hypertension & 0,00 & 0,01 & -6.4 & 0.000 & 0,00 & 0,00 & 0.2 & 0.674 & 96.9 \\
\hline Chronic disease - Coronary heart & 0,00 & 0,01 & -4.7 & 0.000 & 0,00 & 0,00 & -0.1 & 0.959 & 99.4 \\
\hline Chronic disease - Mental illness & 0,02 & 0,02 & -4.8 & 0.000 & 0,02 & 0,02 & 1.4 & 0.016 & 71.0 \\
\hline Chronic disease - Cancer & 0,01 & 0,02 & -5.3 & 0.000 & 0,01 & 0,01 & 0.3 & 0.597 & 94.3 \\
\hline Chronic disease - Other & 0,03 & 0,04 & -2.4 & 0.000 & 0,03 & 0,03 & 1.1 & 0.093 & 57.0 \\
\hline Multiple chronic diseases & 0,01 & 0,02 & -4.5 & 0.000 & 0,01 & 0,01 & -0.4 & 0.520 & 91.5 \\
\hline Full-time & 0,51 & 0,57 & -12.4 & 0.000 & 0,52 & 0,51 & 1.4 & 0.034 & 89.0 \\
\hline Part-time & 0,17 & 0,15 & 3.5 & 0.000 & 0,17 & 0,18 & -0.9 & 0.181 & 74.3 \\
\hline Company size $[1 ; 9]$ & 0,19 & 0,21 & -4.9 & 0.000 & 0,19 & 0,19 & -1.2 & 0.055 & 75.4 \\
\hline Company size $[10 ; 49]$ & 0,23 & 0,28 & -11.6 & 0.000 & 0,22 & 0,23 & -0.8 & 0.223 & 93.5 \\
\hline Company size $[50 ; 499]$ & 0,29 & 0,34 & -10.9 & 0.000 & 0,30 & 0,30 & 0.7 & 0.245 & 93.3 \\
\hline Company size [500; 999] & 0,08 & 0,05 & 13.0 & 0.000 & 0,09 & 0,08 & 3.8 & 0.000 & 70.6 \\
\hline Company size $[1000 ;+]$ & 0,20 & 0,11 & 24.6 & 0.000 & 0,20 & 0,21 & -1.4 & 0.054 & 94.4 \\
\hline Agriculture Fisheries & 0,01 & 0,01 & -2.3 & 0.000 & 0,01 & 0,01 & 0.3 & 0.636 & 88.9 \\
\hline Mining industries & 0,01 & 0,01 & -4.8 & 0.000 & 0,01 & 0,01 & 0.0 & 0.970 & 99.5 \\
\hline Manufacturing industries & 0,00 & 0,00 & -1.4 & 0.006 & 0,00 & 0,00 & 0.3 & 0.673 & 81.3 \\
\hline Production electricity and gas & 0,01 & 0,01 & -4.9 & 0.000 & 0,01 & 0,01 & 0.6 & 0.278 & 87.5 \\
\hline Construction & 0,01 & 0,02 & -6.9 & 0.000 & 0,01 & 0,01 & -0.1 & 0.910 & 99.1 \\
\hline Hotels and restaurants & 0,03 & 0,03 & 0.8 & 0.130 & 0,03 & 0,03 & -0.1 & 0.877 & 86.3 \\
\hline Financial activities & 0,05 & 0,05 & -3.1 & 0.000 & 0,05 & 0,05 & -0.8 & 0.212 & 75.1 \\
\hline $\begin{array}{l}\text { Real estate. rentals. } \\
\text { and business services }\end{array}$ & 0,03 & 0,20 & -54.9 & 0.000 & 0,03 & 0,03 & 0.4 & 0.210 & 99.2 \\
\hline Public administration & 0,01 & 0,01 & -3.2 & 0.000 & 0,01 & 0,01 & 0.7 & 0.228 & 77.0 \\
\hline Education & 0,01 & 0,01 & -0.5 & 0.334 & 0,02 & 0,01 & 1.0 & 0.118 & -113.3 \\
\hline Health and social services & 0,11 & 0,09 & 8.0 & 0.000 & 0,13 & 0,12 & 0.9 & 0.183 & 88.2 \\
\hline Extra-territorial organizations & 0,30 & 0,24 & 14.5 & 0.000 & 0,35 & 0,34 & 1.7 & 0.011 & 88.0 \\
\hline Commerce & 0,00 & 0,00 & -1.1 & 0.027 & 0,00 & 0,00 & 1.0 & 0.075 & 7.0 \\
\hline Paris & 0,22 & 0,19 & 7.1 & 0.000 & 0,23 & 0,25 & -3.3 & 0.000 & 53.5 \\
\hline North-East & 0,19 & 0,21 & -4.3 & 0.000 & 0,20 & 0,19 & 2.2 & 0.000 & 47.6 \\
\hline North-West & 0,17 & 0,19 & -4.0 & 0.000 & 0,19 & 0,18 & 2.2 & 0.001 & 44.0 \\
\hline Center & 0,04 & 0,04 & -2.3 & 0.000 & 0,04 & 0,04 & 0.4 & 0.504 & 81.6 \\
\hline South-East & 0,20 & 0,18 & 3.0 & 0.000 & 0,21 & 0,21 & -1.4 & 0.035 & 53.2 \\
\hline South-West & 0,11 & 0,11 & -0.5 & 0.272 & 0,12 & 0,12 & 0.9 & 0.186 & -58.8 \\
\hline Unemployment rate & 7,90 & 7,95 & -2.8 & 0.000 & 7,86 & 7,85 & 0.3 & 0.635 & 89.1 \\
\hline
\end{tabular}

Source: Panel Hygie 2006-2010 and CBA database compiled by authors. 
Table A2: Covariate balance across Treated and Control groups before and after Matching: Waiting period part of the reform

\begin{tabular}{|c|c|c|c|c|c|c|c|c|c|}
\hline \multirow[b]{2}{*}{ Variable } & \multicolumn{4}{|c|}{ Before matching } & \multicolumn{3}{|c|}{ After matching } & \multirow[b]{2}{*}{$p>t$} & \multirow[b]{2}{*}{$\begin{array}{c}\text { \%reduction } \\
\text { bias }\end{array}$} \\
\hline & Treated & Control & \%bias & $p>t$ & Treated & Control & \%bias & & \\
\hline Women & 0.56 & 0.46 & 21.0 & 0.000 & 0.56 & 0.56 & 1.1 & 0.005 & 94.8 \\
\hline Age $[25 ; 35]$ & 0.24 & 0.23 & 2.1 & 0.000 & 0.24 & 0.22 & 3.7 & 0.000 & -76.1 \\
\hline Age $[36 ; 45]$ & 0.34 & 0.34 & -0.4 & 0.215 & 0.34 & 0.34 & -0.4 & 0.284 & -2.1 \\
\hline Age $[46 ; 55]$ & 0.31 & 0.32 & -3.7 & 0.000 & 0.31 & 0.32 & -2.0 & 0.000 & 46.1 \\
\hline Age $[56 ; 65]$ & 0.11 & 0.10 & 2.6 & 0.000 & 0.11 & 0.11 & -1.6 & 0.000 & 39.4 \\
\hline Q1 salary & 0.37 & 0.15 & 52.6 & 0.000 & 0.37 & 0.36 & 3.2 & 0.000 & 93.9 \\
\hline Q2 salary & 0.28 & 0.24 & 10.0 & 0.000 & 0.28 & 0.29 & -1.7 & 0.000 & 82.5 \\
\hline Q3 salary & 0.21 & 0.34 & -29.4 & 0.000 & 0.21 & 0.21 & 0.1 & 0.760 & 99.6 \\
\hline Q4 salary & 0.14 & 0.28 & -34.0 & 0.000 & 0.14 & 0.15 & -1.6 & 0.000 & 95.3 \\
\hline Employee & 0.54 & 0.30 & 50.3 & 0.000 & 0.53 & 0.51 & 4.3 & 0.000 & 91.4 \\
\hline Laborer & 0.23 & 0.27 & -9.3 & 0.000 & 0.23 & 0.24 & -2.9 & 0.000 & 68.5 \\
\hline Supervisor & 0.09 & 0.18 & -25.6 & 0.000 & 0.09 & 0.10 & -2.5 & 0.000 & 90.1 \\
\hline Executive & 0.10 & 0.25 & -40.7 & 0.000 & 0.10 & 0.12 & -8.9 & 0.000 & 73.3 \\
\hline $\begin{array}{l}\text { Number of GP consultations } \\
\text { the previous year }\end{array}$ & 3.85 & 3.58 & 5.6 & 0.000 & 3.85 & 4.01 & -3.3 & 0.000 & 40.7 \\
\hline $\begin{array}{l}\text { Number of specialist consultations } \\
\text { the previous year }\end{array}$ & 2.15 & 2.12 & 0.6 & 0.058 & 2.19 & 2.24 & -0.9 & 0.023 & -47.0 \\
\hline Number of days in hospital the previous year & 0.10 & 0.11 & -0.6 & 0.097 & 0.10 & 0.12 & -1.2 & 0.001 & -102.0 \\
\hline Chronic disease -Diabetes & 0.02 & 0.02 & 2.0 & 0.000 & 0.02 & 0.02 & -0.6 & 0.123 & 69.6 \\
\hline Chronic disease - Hypertension & 0.01 & 0.01 & 2.2 & 0.000 & 0.01 & 0.01 & -1.4 & 0.001 & 37.6 \\
\hline Chronic disease - Coronary heart & 0.00 & 0.01 & -2.3 & 0.000 & 0.00 & 0.01 & -1.0 & 0.007 & 54.9 \\
\hline Chronic disease - Mental illness & 0.02 & 0.00 & 14.1 & 0.000 & 0.02 & 0.02 & 1.8 & 0.000 & 87.4 \\
\hline Chronic disease - Cancer & 0.01 & 0.01 & -0.6 & 0.069 & 0.01 & 0.01 & 0.1 & 1.000 & 100.0 \\
\hline Chronic disease - Other & 0.04 & 0.03 & 2.7 & 0.000 & 0.04 & 0.04 & -0.7 & 0.104 & 75.5 \\
\hline Multiple chronic diseases & 0.01 & 0.01 & 3.1 & 0.000 & 0.01 & 0.02 & -1.8 & 0.000 & 43.1 \\
\hline Full-time & 0.54 & 0.63 & -17.1 & 0.000 & 0.55 & 0.55 & -0.7 & 0.078 & 95.9 \\
\hline Part-time & 0.19 & 0.11 & 21.9 & 0.000 & 0.19 & 0.19 & 2.6 & 0.000 & 88.2 \\
\hline Company size $[1 ; 9]$ & 0.22 & 0.20 & 4.5 & 0.000 & 0.22 & 0.24 & -4.1 & 0.000 & 9.1 \\
\hline Company size $[10 ; 49]$ & 0.24 & 0.26 & -4.4 & 0.000 & 0.24 & 0.26 & -5.5 & 0.000 & -24.6 \\
\hline Company size $[50 ; 499]$ & 0.37 & 0.38 & -2.0 & 0.000 & 0.38 & 0.35 & 5.7 & 0.000 & -181.6 \\
\hline Company size [500; 999] & 0.06 & 0.08 & -7.5 & 0.000 & 0.06 & 0.05 & 3.0 & 0.000 & 60.2 \\
\hline Company size $[1000 ;+]$ & 0.11 & 0.08 & 10.2 & 0.000 & 0.11 & 0.10 & 1.8 & 0.000 & 82.7 \\
\hline Agriculture Fisheries & 0.03 & 0.00 & 20.5 & 0.000 & 0.03 & 0.02 & 2.7 & 0.000 & 86.9 \\
\hline Mining industries & 0.01 & 0.05 & -26.2 & 0.000 & 0.01 & 0.01 & -0.7 & 0.001 & 97.2 \\
\hline Manufacturing industries & 0.00 & 0.02 & -16.4 & 0.000 & 0.00 & 0.00 & -1.3 & 0.000 & 92.0 \\
\hline Production electricity and gas & 0.01 & 0.06 & -27.0 & 0.000 & 0.01 & 0.01 & -0.6 & 0.003 & 97.6 \\
\hline Construction & 0.01 & 0.11 & -39.7 & 0.000 & 0.01 & 0.02 & -2.1 & 0.000 & 94.6 \\
\hline Hotels and restaurants & 0.02 & 0.08 & -26.3 & 0.000 & 0.02 & 0.02 & 1.4 & 0.000 & 94.7 \\
\hline Financial activities & 0.27 & 0.12 & 38.2 & 0.000 & 0.28 & 0.31 & -5.8 & 0.000 & 84.8 \\
\hline $\begin{array}{l}\text { Real estate. rentals. } \\
\text { and business services }\end{array}$ & 0.04 & 0.08 & -16.6 & 0.000 & 0.04 & 0.03 & 4.0 & 0.000 & 76.2 \\
\hline Public administration & 0.01 & 0.07 & -33.7 & 0.000 & 0.01 & 0.01 & -2.0 & 0.000 & 94.0 \\
\hline Education & 0.01 & 0.03 & -12.3 & 0.000 & 0.01 & 0.01 & 1.1 & 0.000 & 90.8 \\
\hline Health and social services & 0.12 & 0.15 & -9.0 & 0.000 & 0.13 & 0.12 & 3.5 & 0.000 & 60.5 \\
\hline Extra-territorial organizations & 0.19 & 0.15 & 8.9 & 0.000 & 0.20 & 0.18 & 6.0 & 0.000 & 32.7 \\
\hline Commerce & 0.00 & 0.01 & -0.5 & 0.112 & 0.00 & 0.01 & -2.0 & 0.080 & 9.8 \\
\hline Paris & 0.19 & 0.24 & -11.1 & 0.000 & 0.20 & 0.20 & -0.3 & 0.470 & 97.5 \\
\hline North-East & 0.21 & 0.20 & 1.7 & 0.000 & 0.22 & 0.23 & -1.8 & 0.000 & -5.4 \\
\hline North-West & 0.19 & 0.18 & 2.9 & 0.000 & 0.20 & 0.20 & 0.3 & 0.406 & 88.5 \\
\hline Center & 0.04 & 0.04 & -2.2 & 0.000 & 0.04 & 0.04 & -1.3 & 0.001 & 39.2 \\
\hline South-East & 0.19 & 0.19 & -0.7 & 0.032 & 0.20 & 0.19 & 1.0 & 0.011 & -41.5 \\
\hline South-West & 0.12 & 0.13 & -1.0 & 0.003 & 0.13 & 0.13 & 0.8 & 0.036 & 15.2 \\
\hline Unemployment rate & 7.98 & 7.93 & 2.6 & 0.000 & 7.96 & 7.99 & -1.3 & 0.001 & 49.2 \\
\hline
\end{tabular}

Source: Panel Hygie 2006-2010 and CBA database compiled by authors. 
Table A3: Descriptive statistics for Treated and Control groups in pre- and post-reform: Tenure part of the reform

\begin{tabular}{|c|c|c|c|c|c|c|c|c|}
\hline \multirow{3}{*}{ Variable } & \multicolumn{4}{|c|}{ Treated } & \multicolumn{4}{|c|}{ Control } \\
\hline & \multicolumn{2}{|c|}{ Before matching } & \multicolumn{2}{|c|}{ After matching } & \multicolumn{2}{|c|}{ Before matching } & \multicolumn{2}{|c|}{ After matching } \\
\hline & $\begin{array}{l}\text { Pre- } \\
\text { reform }\end{array}$ & $\begin{array}{l}\text { Post- } \\
\text { reform }\end{array}$ & $\begin{array}{c}\text { Pre- } \\
\text { reform }\end{array}$ & $\begin{array}{l}\text { Post- } \\
\text { reform }\end{array}$ & $\begin{array}{l}\text { Pre- } \\
\text { reform }\end{array}$ & $\begin{array}{l}\text { Post- } \\
\text { reform }\end{array}$ & $\begin{array}{c}\text { Pre- } \\
\text { reform }\end{array}$ & $\begin{array}{l}\text { Post- } \\
\text { reform }\end{array}$ \\
\hline Women & 0,58 & 0,56 & 0,58 & 0,56 & 0,58 & 0,57 & 0,50 & 0,49 \\
\hline Age $[25 ; 35]$ & 0,44 & 0,41 & 0,44 & 0,41 & 0,47 & 0,28 & 0,21 & 0,17 \\
\hline Age $[36 ; 45]$ & 0,27 & 0,32 & 0,27 & 0,32 & 0,26 & 0,36 & 0,32 & 0,32 \\
\hline Age $[46 ; 55]$ & 0,16 & 0,20 & 0,16 & 0,20 & 0,17 & 0,26 & 0,31 & 0,33 \\
\hline Age $[56 ; 65]$ & 0,05 & 0,07 & 0,05 & 0,07 & 0,06 & 0,11 & 0,15 & 0,18 \\
\hline Q1 salary & 0,52 & 0,51 & 0,52 & 0,50 & 0,52 & 0,42 & 0,28 & 0,26 \\
\hline Q2 salary & 0,24 & 0,22 & 0,24 & 0,22 & 0,24 & 0,21 & 0,21 & 0,20 \\
\hline Q3 salary & 0,13 & 0,15 & 0,13 & 0,15 & 0,13 & 0,17 & 0,26 & 0,27 \\
\hline Q4 salary & 0,10 & 0,12 & 0,11 & 0,12 & 0,11 & 0,20 & 0,25 & 0,27 \\
\hline Employee & 0,53 & 0,50 & 0,52 & 0,50 & 0,53 & 0,45 & 0,48 & 0,42 \\
\hline Laborer & 0,12 & 0,16 & 0,12 & 0,16 & 0,12 & 0,19 & 0,24 & 0,28 \\
\hline Supervisor & 0,09 & 0,09 & 0,09 & 0,09 & 0,08 & 0,08 & 0,08 & 0,09 \\
\hline Executive & 0,22 & 0,19 & 0,22 & 0,19 & 0,20 & 0,17 & 0,16 & 0,15 \\
\hline $\begin{array}{l}\text { Number of GP consultations } \\
\text { the previous year }\end{array}$ & 3,89 & 3,90 & 3,79 & 3,79 & 3,79 & 3,92 & 4,15 & 4,08 \\
\hline $\begin{array}{l}\text { Number of specialist consultations } \\
\text { the previous year }\end{array}$ & 2,45 & 2,32 & 2,37 & 2,22 & 2,52 & 2,41 & 2,36 & 2,34 \\
\hline $\begin{array}{l}\text { Number of days in hospital the } \\
\text { previous year }\end{array}$ & 1,01 & 0,23 & 0,97 & 0,20 & 0,92 & 0,14 & 0,18 & 0,18 \\
\hline Chronic disease -Diabetes & 0,01 & 0,02 & 0,01 & 0,02 & 0,01 & 0,02 & 0,02 & 0,03 \\
\hline Chronic disease - Hypertension & 0,00 & 0,01 & 0,00 & 0,01 & 0,00 & 0,01 & 0,01 & 0,01 \\
\hline Chronic disease - Coronary heart & 0,00 & 0,01 & 0,00 & 0,00 & 0,00 & 0,01 & 0,01 & 0,01 \\
\hline Chronic disease - Mental illness & 0,02 & 0,02 & 0,01 & 0,02 & 0,01 & 0,03 & 0,02 & 0,03 \\
\hline Chronic disease - Cancer & 0,01 & 0,01 & 0,01 & 0,01 & 0,01 & 0,02 & 0,02 & 0,02 \\
\hline Chronic disease - Other & 0,03 & 0,04 & 0,03 & 0,04 & 0,03 & 0,04 & 0,04 & 0,04 \\
\hline Multiple chronic diseases & 0,01 & 0,02 & 0,01 & 0,02 & 0,01 & 0,02 & 0,02 & 0,02 \\
\hline Full-time & 0,63 & 0,31 & 0,63 & 0,31 & 0,62 & 0,32 & 0,69 & 0,35 \\
\hline Part-time & 0,19 & 0,11 & 0,19 & 0,11 & 0,22 & 0,13 & 0,19 & 0,09 \\
\hline Company size $[1 ; 9]$ & 0,17 & 0,22 & 0,17 & 0,22 & 0,17 & 0,16 & 0,22 & 0,20 \\
\hline Company size $[10 ; 49]$ & 0,22 & 0,23 & 0,22 & 0,23 & 0,22 & 0,19 & 0,29 & 0,26 \\
\hline Company size [50; 499] & 0,30 & 0,29 & 0,30 & 0,29 & 0,30 & 0,34 & 0,34 & 0,36 \\
\hline Company size [500; 999] & 0,09 & 0,07 & 0,09 & 0,08 & 0,08 & 0,08 & 0,05 & 0,05 \\
\hline Company size $[1000 ;+]$ & 0,21 & 0,19 & 0,21 & 0,19 & 0,23 & 0,23 & 0,10 & 0,12 \\
\hline Agriculture Fisheries & 0,01 & 0,01 & 0,01 & 0,01 & 0,01 & 0,01 & 0,01 & 0,01 \\
\hline Mining industries & 0,01 & 0,01 & 0,01 & 0,01 & 0,01 & 0,01 & 0,01 & 0,01 \\
\hline Manufacturing industries & 0,00 & 0,00 & 0,00 & 0,00 & 0,00 & 0,01 & 0,00 & 0,00 \\
\hline Production electricity and gas & 0,01 & 0,01 & 0,01 & 0,01 & 0,01 & 0,01 & 0,01 & 0,01 \\
\hline Construction & 0,01 & 0,01 & 0,01 & 0,01 & 0,01 & 0,02 & 0,02 & 0,02 \\
\hline Hotels and restaurants & 0,03 & 0,02 & 0,03 & 0,02 & 0,03 & 0,03 & 0,02 & 0,03 \\
\hline Financial activities & 0,05 & 0,04 & 0,05 & 0,04 & 0,05 & 0,05 & 0,05 & 0,05 \\
\hline $\begin{array}{l}\text { Real estate. rentals. and business } \\
\text { services }\end{array}$ & 0,04 & 0,02 & 0,04 & 0,02 & 0,04 & 0,05 & 0,18 & 0,23 \\
\hline Public administration & 0,01 & 0,01 & 0,01 & 0,01 & 0,01 & 0,01 & 0,01 & 0,01 \\
\hline Education & 0,02 & 0,01 & 0,02 & 0,01 & 0,02 & 0,02 & 0,01 & 0,02 \\
\hline Health and social services & 0,12 & 0,10 & 0,12 & 0,10 & 0,13 & 0,10 & 0,09 & 0,09 \\
\hline Extra-territorial organizations & 0,31 & 0,29 & 0,31 & 0,29 & 0,31 & 0,39 & 0,23 & 0,25 \\
\hline Commerce & 0,00 & 0,00 & 0,00 & 0,00 & 0,00 & 0,00 & 0,00 & 0,00 \\
\hline Paris & 0,23 & 0,22 & 0,23 & 0,22 & 0,24 & 0,22 & 0,20 & 0,19 \\
\hline North-East & 0,19 & 0,19 & 0,19 & 0,19 & 0,20 & 0,22 & 0,21 & 0,21 \\
\hline North-West & 0,17 & 0,18 & 0,17 & 0,17 & 0,17 & 0,18 & 0,19 & 0,19 \\
\hline Center & 0,04 & 0,04 & 0,04 & 0,04 & 0,04 & 0,04 & 0,04 & 0,04 \\
\hline South-East & 0,20 & 0,20 & 0,20 & 0,20 & 0,21 & 0,20 & 0,19 & 0,18 \\
\hline South-West & 0,12 & 0,11 & 0,12 & 0,11 & 0,12 & 0,12 & 0,12 & 0,11 \\
\hline Unemployment rate & 7,80 & 8,58 & 7,80 & 8,58 & 7,81 & 8,57 & 7,85 & 8,63 \\
\hline
\end{tabular}

Source: Panel Hygie 2006-2010 and CBA database compiled by authors. 
Table A4: Descriptive statistics for Treated and Control groups in pre- and post-reform: Waiting period part of the reform

\begin{tabular}{|c|c|c|c|c|c|c|c|c|}
\hline \multirow{3}{*}{ Variable } & \multicolumn{4}{|c|}{ Treated } & \multicolumn{4}{|c|}{ Control } \\
\hline & \multicolumn{2}{|c|}{ Before matching } & \multicolumn{2}{|c|}{ After matching } & \multicolumn{2}{|c|}{ Before matching } & \multicolumn{2}{|c|}{ After matching } \\
\hline & $\begin{array}{c}\text { Pre- } \\
\text { reform }\end{array}$ & $\begin{array}{c}\text { Post- } \\
\text { reform }\end{array}$ & $\begin{array}{c}\text { Pre- } \\
\text { reform }\end{array}$ & $\begin{array}{l}\text { Post- } \\
\text { reform }\end{array}$ & $\begin{array}{c}\text { Pre- } \\
\text { reform }\end{array}$ & $\begin{array}{c}\text { Post- } \\
\text { reform }\end{array}$ & $\begin{array}{c}\text { Pre- } \\
\text { reform }\end{array}$ & $\begin{array}{l}\text { Post- } \\
\text { reform }\end{array}$ \\
\hline Women & 0,56 & 0,56 & 0,56 & 0,56 & 0,55 & 0,55 & 0,61 & 0,61 \\
\hline Age $[25 ; 35]$ & 0,27 & 0,20 & 0,21 & 0,21 & 0,26 & 0,19 & 0,22 & 0,21 \\
\hline Age $[36 ; 45]$ & 0,34 & 0,33 & 0,34 & 0,32 & 0,35 & 0,33 & 0,33 & 0,32 \\
\hline Age $[46 ; 55]$ & 0,29 & 0,32 & 0,31 & 0,32 & 0,31 & 0,34 & 0,31 & 0,32 \\
\hline Age $[56 ; 65]$ & 0,07 & 0,15 & 0,13 & 0,14 & 0,06 & 0,14 & 0,14 & 0,13 \\
\hline Q1 salary & 0,42 & 0,35 & 0,33 & 0,34 & 0,26 & 0,22 & 0,34 & 0,32 \\
\hline Q2 salary & 0,28 & 0,27 & 0,28 & 0,28 & 0,34 & 0,27 & 0,25 & 0,24 \\
\hline Q3 salary & 0,23 & 0,19 & 0,21 & 0,20 & 0,34 & 0,32 & 0,22 & 0,20 \\
\hline Q4 salary & 0,08 & 0,19 & 0,18 & 0,19 & 0,07 & 0,18 & 0,20 & 0,24 \\
\hline Employee & 0,53 & 0,54 & 0,53 & 0,54 & 0,41 & 0,41 & 0,47 & 0,47 \\
\hline Laborer & 0,23 & 0,23 & 0,23 & 0,23 & 0,35 & 0,35 & 0,21 & 0,21 \\
\hline Supervisor & 0,09 & 0,09 & 0,09 & 0,09 & 0,15 & 0,14 & 0,12 & 0,13 \\
\hline Executive & 0,11 & 0,10 & 0,11 & 0,11 & 0,09 & 0,09 & 0,20 & 0,19 \\
\hline $\begin{array}{l}\text { Number of GP consultations } \\
\text { the previous year }\end{array}$ & 3,91 & 4,12 & 3,79 & 3,90 & 3,77 & 4,00 & 3,92 & 3,99 \\
\hline $\begin{array}{l}\text { Number of specialist consultations } \\
\text { the previous year }\end{array}$ & 2,29 & 2,33 & 2,19 & 2,13 & 2,32 & 2,31 & 2,54 & 2,53 \\
\hline $\begin{array}{l}\text { Number of days in hospital the } \\
\text { previous year }\end{array}$ & 0,14 & 0,16 & 0,11 & 0,10 & 0,16 & 0,20 & 0,19 & 0,21 \\
\hline Chronic disease -Diabetes & 0,01 & 0,02 & 0,01 & 0,02 & 0,01 & 0,02 & 0,01 & 0,02 \\
\hline Chronic disease - Hypertension & 0,01 & 0,01 & 0,01 & 0,01 & 0,00 & 0,01 & 0,01 & 0,01 \\
\hline Chronic disease - Coronary heart & 0,00 & 0,01 & 0,00 & 0,01 & 0,00 & 0,01 & 0,00 & 0,01 \\
\hline Chronic disease - Mental illness & 0,02 & 0,02 & 0,02 & 0,02 & 0,01 & 0,01 & 0,02 & 0,02 \\
\hline Chronic disease - Cancer & 0,01 & 0,02 & 0,01 & 0,02 & 0,01 & 0,02 & 0,01 & 0,02 \\
\hline Chronic disease - Other & 0,03 & 0,05 & 0,03 & 0,04 & 0,03 & 0,05 & 0,04 & 0,05 \\
\hline Multiple chronic diseases & 0,01 & 0,02 & 0,01 & 0,02 & 0,01 & 0,02 & 0,01 & 0,02 \\
\hline Full-time & 0,67 & 0,34 & 0,67 & 0,34 & 0,74 & 0,37 & 0,67 & 0,32 \\
\hline Part-time & 0,23 & 0,12 & 0,23 & 0,12 & 0,19 & 0,10 & 0,25 & 0,14 \\
\hline Company size $[1 ; 9]$ & 0,22 & 0,22 & 0,22 & 0,22 & 0,22 & 0,22 & 0,27 & 0,28 \\
\hline Company size $[10 ; 49]$ & 0,24 & 0,23 & 0,24 & 0,23 & 0,29 & 0,29 & 0,25 & 0,25 \\
\hline Company size [50; 499] & 0,38 & 0,37 & 0,38 & 0,37 & 0,39 & 0,39 & 0,34 & 0,33 \\
\hline Company size [500; 999] & 0,06 & 0,06 & 0,06 & 0,06 & 0,06 & 0,06 & 0,03 & 0,03 \\
\hline Company size $[1000 ;+]$ & 0,11 & 0,11 & 0,11 & 0,11 & 0,04 & 0,04 & 0,11 & 0,11 \\
\hline Agriculture Fisheries & 0,03 & 0,03 & 0,03 & 0,03 & 0,00 & 0,00 & 0,00 & 0,00 \\
\hline Mining industries & 0,01 & 0,01 & 0,01 & 0,01 & 0,07 & 0,06 & 0,01 & 0,02 \\
\hline Manufacturing industries & 0,00 & 0,00 & 0,00 & 0,00 & 0,00 & 0,00 & 0,00 & 0,00 \\
\hline Production electricity and gas & 0,01 & 0,01 & 0,01 & 0,01 & 0,01 & 0,01 & 0,01 & 0,01 \\
\hline Construction & 0,01 & 0,01 & 0,01 & 0,01 & 0,09 & 0,09 & 0,02 & 0,02 \\
\hline Hotels and restaurants & 0,02 & 0,02 & 0,02 & 0,02 & 0,11 & 0,10 & 0,02 & 0,02 \\
\hline Financial activities & 0,28 & 0,25 & 0,28 & 0,25 & 0,05 & 0,04 & 0,28 & 0,24 \\
\hline $\begin{array}{l}\text { Real estate. rentals. and business } \\
\text { services }\end{array}$ & 0,04 & 0,04 & 0,04 & 0,04 & 0,13 & 0,12 & 0,03 & 0,03 \\
\hline Public administration & 0,01 & 0,01 & 0,01 & 0,01 & 0,00 & 0,00 & 0,01 & 0,01 \\
\hline Education & 0,01 & 0,01 & 0,01 & 0,01 & 0,00 & 0,00 & 0,01 & 0,01 \\
\hline Health and social services & 0,13 & 0,11 & 0,13 & 0,11 & 0,17 & 0,15 & 0,16 & 0,15 \\
\hline Extra-territorial organizations & 0,19 & 0,18 & 0,19 & 0,18 & 0,31 & 0,29 & 0,15 & 0,15 \\
\hline Commerce & 0,00 & 0,00 & 0,00 & 0,00 & 0,00 & 0,00 & 0,00 & 0,00 \\
\hline Paris & 0,19 & 0,19 & 0,19 & 0,19 & 0,14 & 0,14 & 0,24 & 0,24 \\
\hline North-East & 0,21 & 0,21 & 0,21 & 0,21 & 0,23 & 0,23 & 0,21 & 0,21 \\
\hline North-West & 0,19 & 0,19 & 0,19 & 0,19 & 0,20 & 0,20 & 0,18 & 0,18 \\
\hline Center & 0,04 & 0,04 & 0,04 & 0,04 & 0,05 & 0,05 & 0,04 & 0,04 \\
\hline South-East & 0,19 & 0,19 & 0,19 & 0,19 & 0,20 & 0,20 & 0,20 & 0,20 \\
\hline South-West & 0,12 & 0,12 & 0,12 & 0,12 & 0,15 & 0,15 & 0,11 & 0,11 \\
\hline Unemployment rate & 7,85 & 8,64 & 7,85 & 8,64 & 7,87 & 8,66 & 7,85 & 8,61 \\
\hline
\end{tabular}

Source: Panel Hygie 2006-2010 and CBA database compiled by authors. 


\section{DERNIERS NUMÉROS PARUS :}

téléchargeables à partir du site http://ceet.cnam.fr/

$\boldsymbol{N}^{\circ} 207$ Trajectoires professionnelles et formation continue pendant la crise sanitaire : un éclairage à partir des situations des auditeurs du Cnam

Christine Erhel, Mathilde Guergoat-Lariviere, Mathilde Nutarelli, Julian Pelloux, THERESE REBIERE

septembre 2021

$\mathbf{N}^{\circ} 206$ Why Do Employees Participate in Innovation? Skills and Organisational Design Issues and The Ongoing Technological Transformation

NATHALIE GREENAN, SiLVIA NAPOLITANO

juin 2021

$\mathbf{N}^{\circ} 205$ Les métiers "de deuxième ligne" de la crise du Covid-19 : quelles conditions de travail et d'emploi dans le secteur privé?

Thomas Amosse, Mikael Beatriz, Christine Erhel, MaliK KOUBI, Amelie Mauroux mai 2021

$\mathbf{N}^{\circ} 204$ Working time arragements, inovvation and job satisfaction: a workplace level analysis for France

Christine ERHEL, MATHILDE GUERGOAT-LARIVIERE, MALO MOFAKHAMI

mars 2021

$\mathbf{N}^{\circ} 203$ Les canaux de (non) recrutement des chômeurs. Une exploration à partir de l'enquête Ofer 2016

YANNICK FONDEUR, CLAUDE MINNI

novembre 2020

$\mathbf{N}^{\circ} 202$ Les repères de la sélection à l'embauche et leur évaluation

GUILLEMETTE DE LARQUIER, EMMANUELLE MARCHAL

septembre 2020

$\mathbf{N}^{\circ} 201$ Les pratiques de recrutement des entreprises : un pouvoir de segmentation et de valorisation GUILLEMETTE DE LARQUIER, GÉRALDINE RIEUCAU

février 2020

$\mathbf{N}^{\circ} 200 \quad$ L'espace de l'articulation emploi/hors-emploi chez les indépendant.e.s

JULIE LANDOUR

novembre 2019

$\mathbf{N}^{\circ} 199$ Le présentéisme au travail. Mieux évaluer pour mieux prévenir SYLVIE HAMON-CHOLET, JOSEPH LANFRANCHI juin 2019

$\mathbf{N}^{\circ} 198 \quad$ L'analyse des données de concours au regard des discriminations à l'entrée dans la Fonction Publique d'État

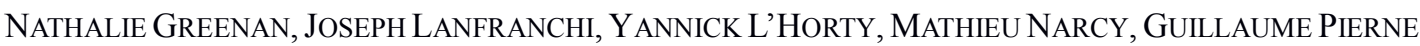
juin 2019 